\title{
Horse flies (Diptera: Tabanidae) of the north-eastern parts of the Hercynian mountains and adjacent localities (Czech Republic)
}

\author{
Jan Ježek, Markéta Omelková \& Josef Hájek
}

\begin{abstract}
Horse flies (Diptera: Tabanidae) of the north-eastern parts of the Hercynian mountains and adjacent localities (Czech Republic). - Acta Mus. Siles. Sci. Natur., 66: 7-34, 2017.

Abstract: The horse fly fauna of the NE parts of the Hercynicum (36 species of 8 genera, including one ssp. and one recognized form) is relatively diverse, including $65.5 \%$ of the Tabanid species recorded from the Czech Republic. All literature records are referred to, and 136 new localities added. The most interesting finds during our faunistic survey were the nationally scarce Silvius alpinus (Scopoli, 1763), Hybomitra arpadi (Szilády, 1923), H. kaurii Chvála \& Lyneborg, 1970 and H. nitidifrons confiformis Chvála \& Moucha, 1971; in spite of literature records H. lurida (Fallén, 1817) was not re-found. Atylotus plebejus (Fallén, 1817) and Chrysops rufipes Meigen, 1830 are classified as endangered species in the Czech Republic, and Glaucops hirsutus (Villers, 1789) as vulnerable.
\end{abstract}

Key words: Diptera, Tabanidae, faunistics, new localities, distribution, Hercynicum, north-eastern Bohemia, north-western Moravia, Czech Republic.

\section{Introduction}

The horse flies are insects of considerable economic importance, with a body size 6-27 $\mathrm{mm}$ in Europe (Chvála 1980). The females (Fig. 10) are usually blood-sucking, and known to be vectors of diseases. These infections may be dangerous to wild and domestic animals or man (see Chvála, Lyneborg \& Moucha 1972). The males (Fig. 11) generally feed on flower nectar, as do the females of some non-biting species. The eggs are mostly laid in masses on littoral vegetation just above water. The larvae may be hydrophilous, semihydrophilous (Figs 12,13 ) or edaphic, the praepupal larval instar migrates to a drier place and pupates; for more information, see Chvála \& Ježek (1997). The family Tabanidae contains 4434 species worldwide, including fossil taxa (Pape et al. 2011); 541 species occur in the Palaearctic Region (Chvála 2007), 213 in Europe (Chvála 2009), and 55 are listed for the Czech Republic, 50 in Bohemia, 50 in Moravia (Ježek \& Barták 2005, Chvála 2009, Ježek \& Omelková 2012). The NE Hercynicum of CZ, especially the Orlické hory PLA and adjacent localities, have not yet been sytematically explored. Only a few dipterists have visited this area to collect flies and published extensive data (Czižek 1907, 1908, Vimmer 1913, Landrock 1907, 1932, Moucha \& Chvála 1955, 1956a, b, c, 1958a, 1959c, 1961, 1967, 1968, 1969, Ježková 1974, Formánek 1982). The diversity of the horse fly fauna of several other regions of the Czech Republic has previously been studied in detail e.g. by Ježek 1999, Ježek \& Barták 2000, Ježek et al. 2005, 2008, 2012a,b, Ježek \& Omelková 2012 and Ježek \& Heřman 2014. The conservation status of species has been discussed generally by Ježek \& Barták 2005.

\section{Material and methods}

This study is based on 5831 specimens of Tabanidae, collected mainly in the Orlické hory PLA and adjacent areas (predominantly NE Hercynicum of CZ) between 1964 and 2012, however, sporadic older historical specimens were collected between 1956 and 1963 and several individuals were added during preparation of this manuscript. The general natural history of the whole area was characterised by Faltysová et al. 
(2002), Šafář J. et al. (2003) and Faltysová, Bárta et al. (2004). Most of the material was collected using Malaise traps (emptied about three-weekly, generally only the date on which samples were removed is quoted in the list of material examined in the Results section), occasionally supplemented by Manitoba traps, yellow pan traps, emergent - and pyramidal traps and sweep-netting. All material from traps originally stored in alcohol, as well as dry material from sweeping, was pinned for deposition in collections and for further study, and determined by the first author; the material examined is deposited in the National Museum (Praha), the Museum of Eastern Bohemia (Hradec Králové), the Faculty of Science of Masaryk University (Brno) and the private collection of Jan Zuska (Praha). Most of the recent data comes from a total of 136 localities, see the numbered list of collecting sites, with detailed information included and supplied with the codes of fields in the faunistic and floristic grid mapping system for Central Europe (Ehrendorfer \& Hamann 1965, Zelený 1972, Pruner \& Míka 1996). Identification keys used: Ježek (1977b, 1980), Leclercq $(1960,1967)$ and Olsufjev (1977). Nomenclature follows Chvála et al. (1972), Chvála (1988, 2007) and Moucha (1976).

The following abbreviations are applied: EN - endangered species, NM - National Monument, NNR National Nature Reserve, NR - Nature Reserve, NS - nationally scarce species, PLA - Protected Landscape Area, VU - vulnerable species; NMPC - collection of the National Museum, Praha; MVCH - collection of the Museum of Eastern Bohemia, Hradec Králové; PFMU - collection of the Faculty of Science of Masaryk University, Brno; ZPC - private collection of Jan Zuska; $\mathrm{m}^{*}$ - male, $\mathrm{f}^{*}$ - female; MT - Malaise trap, SW sweep-netting, YPT - yellow pan traps, ET - emergent trap, PT - pyramidal trap, MB - Manitoba trap; C Pavel Chvojka leg., Ce - Adolf Čejchan leg., D - Miroslav Doležal leg., F - Martin Fikáček leg., H - Josef Hájek leg., Ho - Aleš Hozák leg., J - Jan Ježek leg., Je - Věra Ježková leg., JiH - Jiří Hájek leg., M - Jan Macek leg., Ma - Marie Marková leg., Mm - Miroslav Mikát leg., Mo - Bohumil Mocek leg., Ms - Jaroslav Máslo leg., Mtj - Jan Matějíček leg., P - Jiří Preisler sort., Pr - Jaroslav Prouza leg., R - Rudolf Rozkošný leg., Ru - Adolf Růžička leg., S - Hana Šuláková leg., Su - Oldřich Sucharda leg., V - Antonín Vimmer leg., Va - Miloš Vašek leg., Ve - Jiří Veselý leg., Z - Vladimír Zeman leg., Zu - Jan Zuska leg.

\section{List of collecting sites}

Each entry in this list is arranged as follows: number of locality, name of the collecting site (name of nearest village or town), grid mapping codes sensu Zelený (1972) and Pruner \& Míka (1996), geomorphological units, brief characteristics of biotopes incl. elevation etc.

1. Adamovo jezero lake (5965), Petrovice env., small natural water reservoir with rapid deterioration in quality, wet meadow, forest brook

2. Amerika (5865) near Klášterec nad Orlicí, Orlické hory PLA, forest

3. Anenský vrch Mt. (991 m a.s.l. )(5764), Horní Rokytnice env., Orlické hory PLA, forest

4. Antoniino údolí valley (5763), Velký Uhřínov env., Bělá river, Orlické hory PLA, forest

5. Bartošovice v Orlických horách (5865), Divoká Orlice river, Orlické hory PLA, meadows

6. Bedřichovka (5764) near Orlické Záhoří, Orlické hory PLA, wood margin, meadows, forest spring area, swamps, helocrene, brook

7. Benátky (5763), Liberk env., Kněžna brook, forest

8. Bernartice - Vrchová (5361), $10 \mathrm{~km} \mathrm{~N}$ of Trutnov, damp meadow, $579 \mathrm{~m}$ a.s.1.

9. Between Hynčice pod Sušinou and Chrastice (5867), Staré Město pod Sněžníkem env., Králický Sněžník Mts, Chrastický potok brook, alluvial meadows, forests

10. Between Karlova Studánka and Praděd Mt. (1491 m a.s.1.)(5969), waterfalls of Bílá Opava river (NNR), Jeseníky PLA, wet rocky walls and spring areas, hygropetric zones, waterlogged spots and small streams

11. Between Pasínky and Bystřina (5867), Chrastice env., gamekeeper's lodge, Prudký potok brook, pastures, alluvial meadows, forests

12. Between Podlesí and Vysoký Potok (5967), Hanušovice env., pastures and brooks

13. Between Šanov and Jeřáb Mt. (1002.8 m a.s.1.) (5966), forests, streams, spring areas, swamps

14. Běleč nad Orlicí (5861), air range, forests, swampy clearings and Výskyt pond, $240 \mathrm{~m}$ a.s.l.

15. Bělečko (5861) near Býšt' env. Hradec Králové, forests, brooks, 265 m a.s.1.

16. Bohuslavice nad Metují (5662), Náchod distr., floodplain forest, $284 \mathrm{~m}$ a.s.l.

17. Borohrádek $(5862,5962)$, Rychnov nad Kněžnou env., pinewoods, Tichá Orlice river, 258 m a.s.l.

18. Broumarské slatiny swamps NM (5762), Opočno env., Broumar pond, wet meadows

19. Bruntál (6070), Nízký Jeseník Mts, forests and pastures, $547 \mathrm{~m}$ a.s.l.

20. Bukačka NNR (5664), environs of Šerlich Mt. (1025 m a.s.l.), Orlické hory PLA, forest, brook, upper and down wet meadows (Fig. 2)

21. Buková hora Mt. (958.0 m a.s.1.) (5966), Čenkovice env., forest and meadows, springs

22. Častolovice (5863), palace gardens, ponds, brooks, gutters, Bělá river, $268 \mathrm{~m}$ a.s.1.

23. Čenkovička brook NM (5965) between Čenkovice and Bystřec, forest, wet meadows

24. Černíkovice (5863), environs of Solnice, Bělá river, ponds, 316 m a.s.l. 


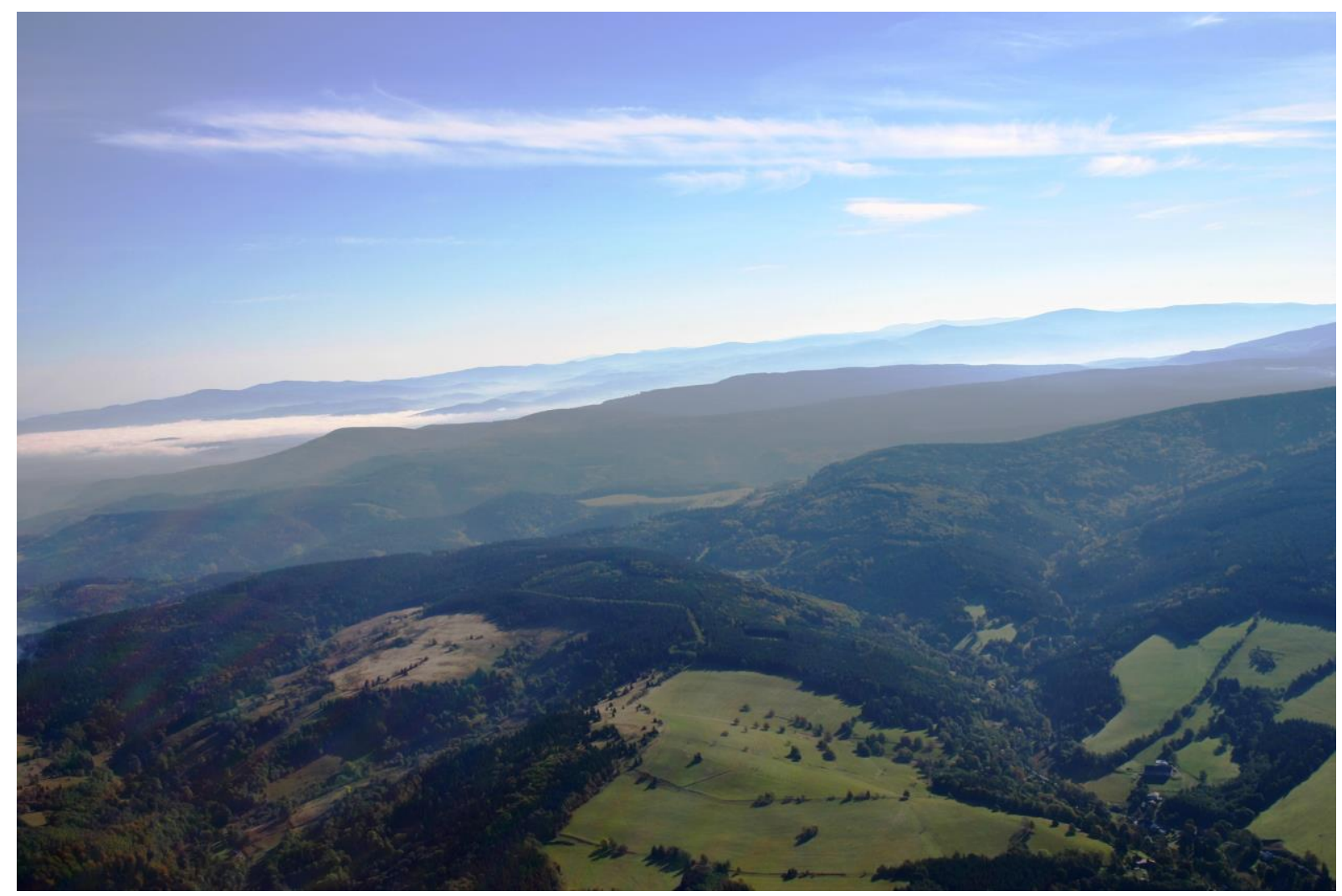

Fig 1: Aerial view of the Orlické hory Mts; the landscape in a vicinity of Olešnice v Orlických horách. Photo by Jan Mocek.

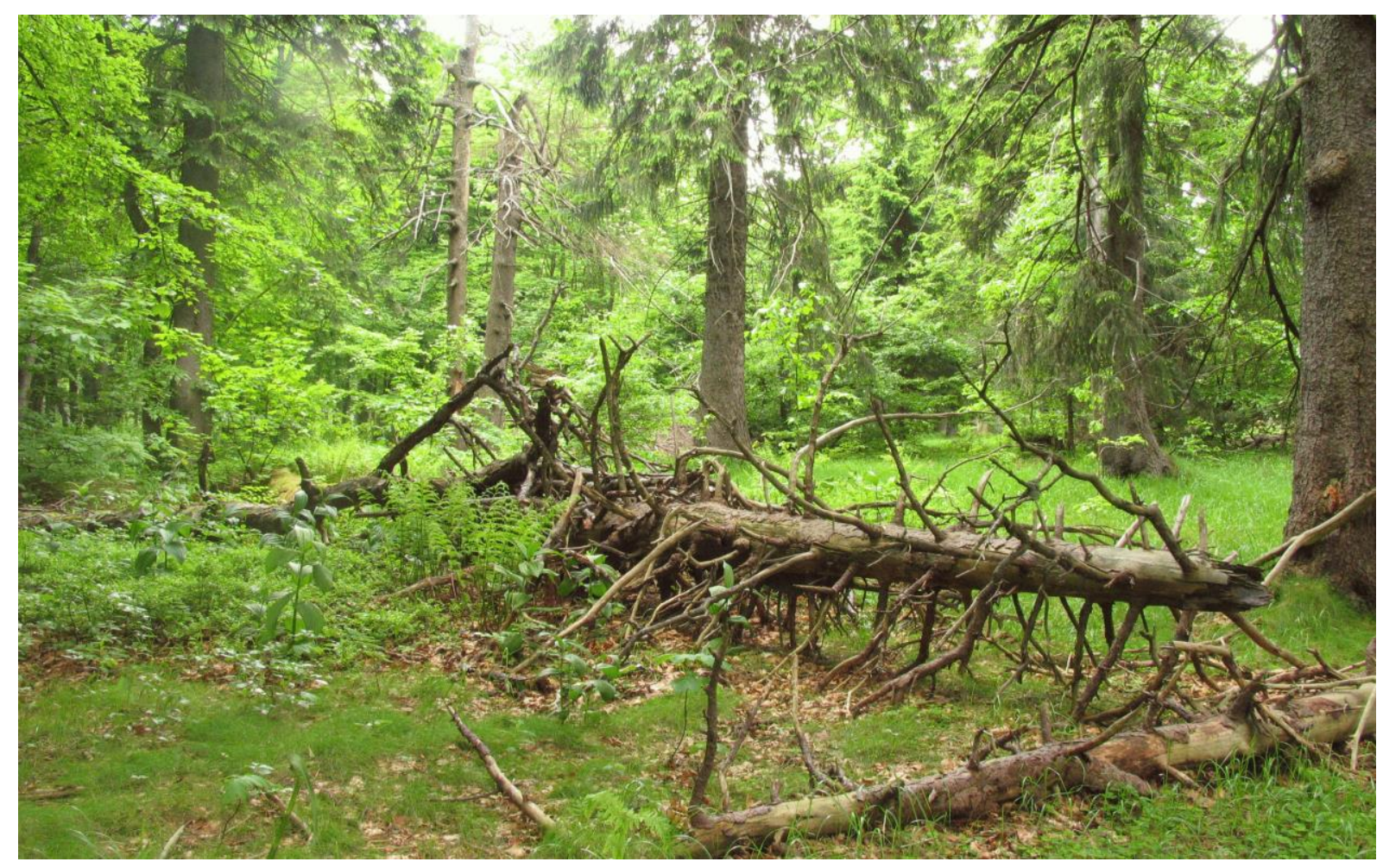

Fig 2: Bukačka NNR; wet mountain primary forest and meadows - suitable area for the occurence of horse flies. Photo by Josef Hájek. 
25. Černý důl valley (5765) near Panské Pole, environs of Neratov, Orlické hory PLA, forest, spring area, small brook (Fig. 5)

26. Černý potok brook near Malá Deštná Mt. (1090 m a.s.1.) (5664), Orlické hory PLA, forest

27. Červená Voda (5966), Březná brook, forests, pastures, 532 m a.s.l.

28. Červený Potok (5866), Králíky env., Morava river, forests, meadows, $540 \mathrm{~m}$ a.s.l.

29. Česká Třebová (6064, 6164), Třebovka river, forests and meadows, 375 m a.s.l.

30. České Meziříčí - Zbytka NR (5762), a large complex of floodplains and fen meadows in the meander of Zlatý potok brook, Quercetum, $250 \mathrm{~m}$ a.s.1.

31. Č́íhalka -Vápenka (5664), environs of Olešnice v Orlických horách, Orlické hory PLA, marshes

32. Deštné v Orlických horách (5664), Orlické hory PLA, wet meadows

33. Dolní Čermná (6065), settlement, Čermná brook (downstream), alluvial meadows

34. Dolní Hedeč (5966), environs of Králíky, monasterial garden and meadows

35. Dolní Lipová (5768), Jeseníky PLA, gardens of a health resort, meadows and forests

36. Dolní Morava (5866), Králický Sněžník Mts, Morava river, alluvial meadows

37. Dolní Radechová (5562) nr. Náchod, Velký rybník pond env., 359 m a.s.l.

38. Dubno NR (5562) env. Česká Skalice, damp meadow, 300 m a.s.l.

39. Hemže - Mýtkov (5963), between Choceň and Brandýs nad Orlicí, Tichá Orlice river, alluvial meadows

40. Heroltice (6066), environs of Štíty, forests and pastures, brooks, $505 \mathrm{~m}$ a.s.l.

41. Heřmanice (5866), environs of Králíky, forests and meadows, Sázavský potok brook, 580 m a.s.l.

42. Hoděšovice (5861) env. Třebechovice pod Orebem, „U Mazury“, boggy meadow, 292 m a.s.l.

43. Horní Čermná (6065), settlement, Čermná brook (upstream), alluvial meadows

44. Horní Lipka (5866), environs of Červený Potok, Lipkovský potok brook, alluvial meadows

45. Horní Morava - Zátiší (5866), Králický Sněžník Mts, slope spring areas, small garden water reservoirs, forests

46. Horní Ředice - Mordýř pond (5861), environs of Holice, water reservoirs of fishery, forest edges, wet meadows, swamps

47. Hořečky NR (5664), environs of Olešnice v Orlických horách, Orlické hory PLA, forest edge, meadow

48. Hradec Králové - Malšovice (5761, 5861), Orlice river, oxbow lakes, 232 m a.s.l.

49. Hradec Králové - Nový Hradec Králové (5861), forest edges, 276 m a.s.l.

50. Hradec Králové - Piletice (5761), Piletický potok brook, 238 m a.s.1.

51. Hradec Králové - Pivovarská flošna (5761), rests of an army fort near Orlice river

52. Hronov (5562), Broumovsko PLA, Metuje river, alluvial meadows, forests

53. Hustír̆any (5660) env. Jaroměr̆, mixed forest, $281 \mathrm{~m}$ a.s.l.

54. Jablonné nad Orlicí (5965), Tichá Orlice river, alluvial meadows, forests

55. Jadrná (5764), environs of Orlické Záhoří, Orlické hory PLA, forest streams and meadows

56. Jelení lázeň peatbog NR (5664), environs of Malá Deštná Mt. (1090 m a.s.1.), Orlické hory PLA, small natural lake with peat-moss, Sphagnetum, clearings of a reduced forest (Fig. 4)

57. Jetřichov (5363), Jetřichovské mokřadní louky meadows NR, environs of Meziměstí, Broumovsko PLA, wet meadows, $460 \mathrm{~m}$ a.s.l.

58. Jiskrovo údolí valley (5963), environs of Brandýs nad Orlicí, small forest brooks and swamps

59. Julinčino Údolí (5864), environs of Rokytnice v Orlických horách, Říčka brook, Orlické hory PLA, forest spring areas

60. Kamenný kopec hill (625.0 m a.s.1.) (5867), environs of Pusté Žibřidovice, pastures

61. Karlov pod Pradědem (5969), Moravice river, Jeseníky PLA, marshes, overhanging boughs of trees in river bed

62. Karlova Studánka (5969), Jeseníky PLA, Bílá Opava river, forest spring areas, small brooks, meadows and peat bogs

63. Klečkov - Poříčí (5763), Klečkov (ruin of the castle) and Poříčí hill (657 m a.s.l.), Orlické hory PLA, forest windbreaks, degraded trickle system, swamps

64. Koruna (6166) nr. Třebařov, Lanškroun env., Ospitský potok brook (approximately 320 m a.s.1.), floodplain, marshes

65. Kouty nad Desnou (5868), Divoká Desná river, Jeseníky PLA, spring areas, streams, 565 m a.s.1.

66. Králický Sněžník Mt. (1423.7 m a.s.1.) (5767), NNR, spring of the Morava river, timber line, meadow slopes

67. Králický Sněžník Mts - U strašidel timber chalet (5866), stream waterfall, deep ravine, spring areas, forest

68. Králíky - Vyhlídka hill (737.4 m a.s.1.) (5866), shrubby meadows, pastures

69. Kunčice (5867), environs of Staré Město pod Sněžníkem, Kunčický potok brook, forest, pastures

70. Lázně Bohdaneč - ponds (5859-60;5959-60), Bohdanečský rybník and rybník Matka ponds NNR, environs of Lázně Bohdaneč, shaded drains and swamps, alder woods

71. Libišany (5860) env. Hradec Králové, Na Bahnech (Libišanské bažiny swamps), 230 m a.s.l.

72. Lohenice (5959) env. Lázně Bohdaneč, Labe river, oxbow lakes, meadows, $212 \mathrm{~m}$ a.s.1. 


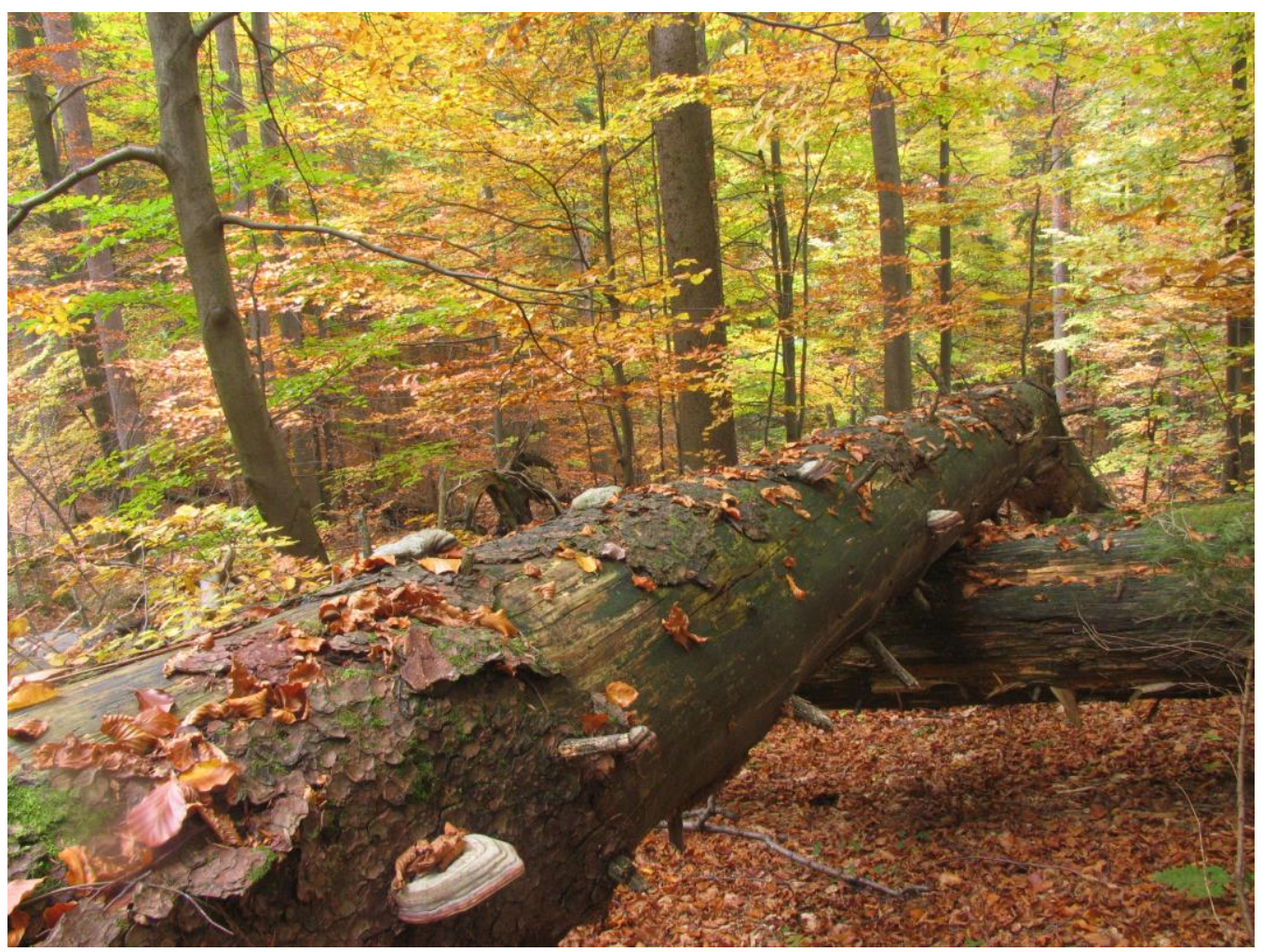

Fig 3: Trčkov NNR; swampy primary beech-fir wood. Photo by Josef Hájek.

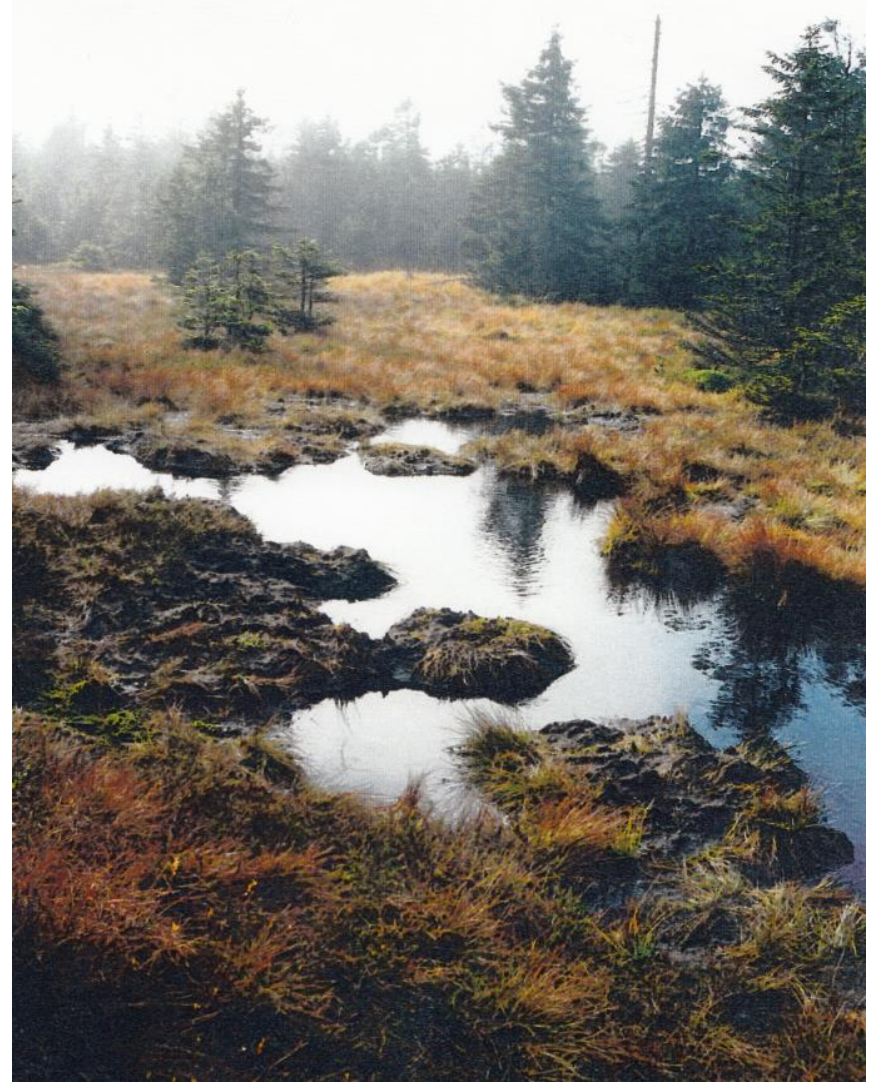

Fig 4: Jelení Lázeň peatbog NR - environs of Malá Deštná Mt.; collecting site of adults of Hybomitra spp. Photo by Josef Hájek. 
73. Mělčany - Zlatý potok brook $(5762,5763)$, environs of Dobruška, meanders of water flow, alluvial meadows, arable land

74. Moravský Karlov (5966), environs of Červená Voda, Březná brook, forests, 545 m a.s.l.

75. Na Plachtě NM (5861) env. Nový Hradec Králové, ponds, swamps, sands and heathlands

76. Nebeská Rybná (57-5864), environs of Rokytnice v Orlických horách, Orlické hory PLA, pastures, meadows, spring area, wallows, small brook

77. Nepomuky (6065), environs of Lanškroun, Moravská Sázava river, forest

78. Neratov (5765), Divoká Orlice river, Orlické hory PLA, pastures, forests,

79. Nová Ves env. Borohrádek (5962), Malý Karlov pond, damp meadow, 270 m a.s.l.

80. Nová Ves env. Orlické Záhoří (5765), Divoká Orlice river, Orlické hory PLA, meanders, alluvial meadows

81. Olešnice v Orlických horách (5663), Orlické hory PLA, pastures, small brooks, spring areas (Fig. 1)

82. Orlické Záhoři (5764), Orlické hory PLA, forest, boggy area, floodplain of the Divoká Orlice river, small streams, $680 \mathrm{~m}$ a.s.1. (Fig. 8)

83. Osíkov (5967), between Hanušovice and Šumperk, pastures, forests, 620 m. a.s.l.

84. Ošerov (5663) near Deštné v Orlických horách, Orlické hory PLA, wet meadows, brook

85. Peklo - Jestřebí (5663), environs of Náchod, Metuje river and Olešenka brook, forests, alluvial meadows

86. Peklo nad Zdobnicí (5863), environs of Vamberk, Zdobnice river, vertical bank with unmodified natural berms, overhanging boughs

87. Pěticestí crossway 1004.0 m a.s.1. (5764), environs of Zdobnice, Orlické hory PLA, forests, spring areas

88. Plchůvky $(5962,5963)$ nr. Choceň, Tichá Orlice river, 277 m a.s.l.

89. Podlesí, environs of Neratov (5765), Orlické hory PLA, Divoká Orlice river, alluvial meadows, forests

90. Pod Sfingou NM (5764), Orlické hory PLA, rocky barrier (953.3 m a.s.1.) in forest stands near Luisino Údolí

91. Pod Zakletým NR (5764), Hluboký potok brook near Zakletý Mt. 991 m a.s.l., environs of Ř́čky, Orlické hory PLA, spring areas, forests

92. Prameny near Žárová (5967), environs of Hanušovice, pastures, meadows, forests

93. Prochody (5962), environs of Újezd u Chocně, pond, forests, $598 \mathrm{~m}$ a.s.l.

94. Prostřední Lipka (5866), environs of Králíky, Lipkovský potok brook, alluvial meadows, pastures

95. Prudký potok brook - Mokřiny (5867), environs of Babuše log-cabin, Králický Sněžník NNR, rapid flow, swamps, forest

96. Přelouč - Slavíkovy ostrovy (5959), Labe river floodplain and Neratovský potok brook, meadows and swamps, $212 \mathrm{~m}$ a.s.l.

97. Račice nad Trotinou (5660), Jaroměř env., xerotherm habitats, $250 \mathrm{~m}$ a.s.1.

98. Rašeliniště Kačerov NR peatbog (5764), Orlické hory PLA, trees, saplings, shrubs, grasses and mosses

99. Rašeliniště Pod Předním vrchem peatbog (5865), environs of Bartošovice v Orlických horách, Orlické hory PLA, wet meadows, large shaded spring area, swamps, rills, ditches

100. Rokytnice v Orlických horách (5864), Rokytenka brook, Orlické hory PLA, fields, meadows, forests

101. Rožmitál env. Broumov (5364), Broumovsko PLA, slopes of Cikánský vrch hill, forest drives (560 m a.s.1.) $\mathrm{N}$ of a quarry

102. Ruprechtice (5363), environs of Broumov, Broumovsko PLA, small forest ponds, streams, swamps

103. Ruské údolí valley nr. Olešnice v Orlických horách (5663), Orlické hory PLA, brook, swamps, springs

104. Sedloňov - Polom (5663), environs of Olešnice v Orlických horách, Orlické hory PLA, forester's house, range land, helocrene area, small stocked pond

105. Selské vrchy hills - Mlýnský potok brook (5866), environs of Velká Morava, forests, swamps

106. Sítovka NM (5861) env. Nový Hradec Králové, mixed forest (Pinus, Quercus and Tilia), 277 m a.s.l.

107. Sklené (5867), environs of Vysoký Potok, Malá Morava brook, pastures, $690 \mathrm{~m}$ a.s.l.

108. Skuhrov nad Bělou (5763), Bělá river, alluvial meadows, forests, $379 \mathrm{~m}$ a.s.1.

109. Sopotnice - Pod horou (5964), environs of Potštejn, fields, marshes, trickles, gutters

110. Studnice (5562), environs of Česká Skalice, forest, ponds, $342 \mathrm{~m}$ a.s.l.

111. Suchý vrch Mt. (995.0 m a.s.1.) (5966), environs of Králíky, Mladkov and Lichkov, forests, spring areas, swamps, pastures (Fig. 9)

112. Šerlich Mt. (1025 m a.s.1.) (5664), Orlické hory PLA, spring area, well and valley of Bělá stream

113. Šerlišský Mlýn hostel (5664) near Šerlich Mt. (1025 m a.s.1.), Orlické hory PLA, forest brook

114. Špičák quarry near Plasnice (5663), environs of Deštné v Orlických horách, Orlické hory PLA, rocky walls, shrubs, pools, xerophilous vegetation

115. Štíty - Na Kluči (6066), forest edge, pastures, meadows

116. Trčkov NNR (5664), Orlické hory PLA, primary beech-fir wood, helocrene area, windthrow calamity (Fig. 3)

117. Trčkovská louka meadow (5664), environs of Trčkov, Orlické hory PLA, pasture springs, forest edge, shrubs

118. Třesice (5859) env. Chlumec nad Cidlinou, Třesický rybník pond, 225 m a.s.1 


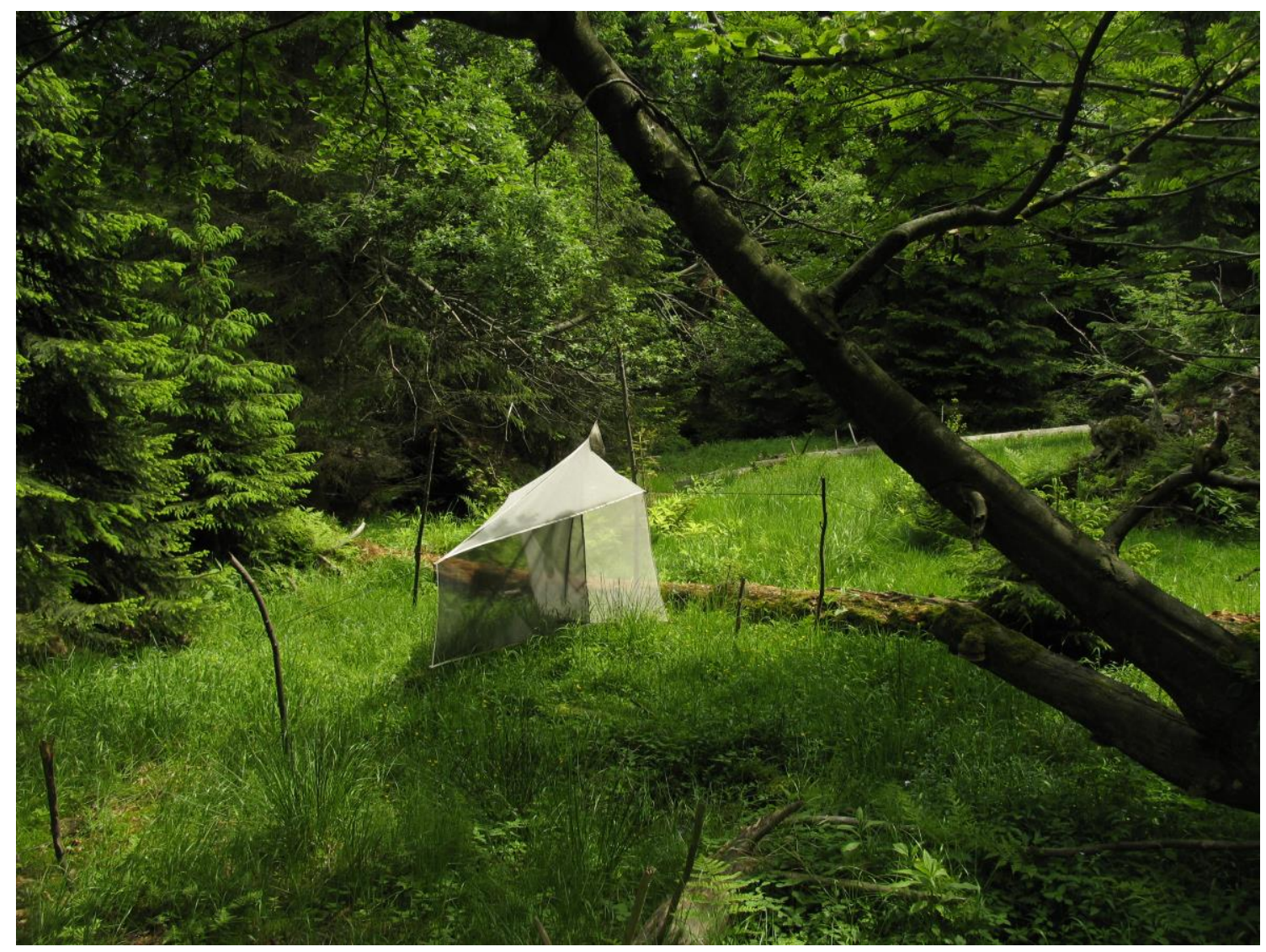

Fig 5: Černý Důl NR; Malaise trap for monitoring of insect activities. Photo by Josef Hájek.

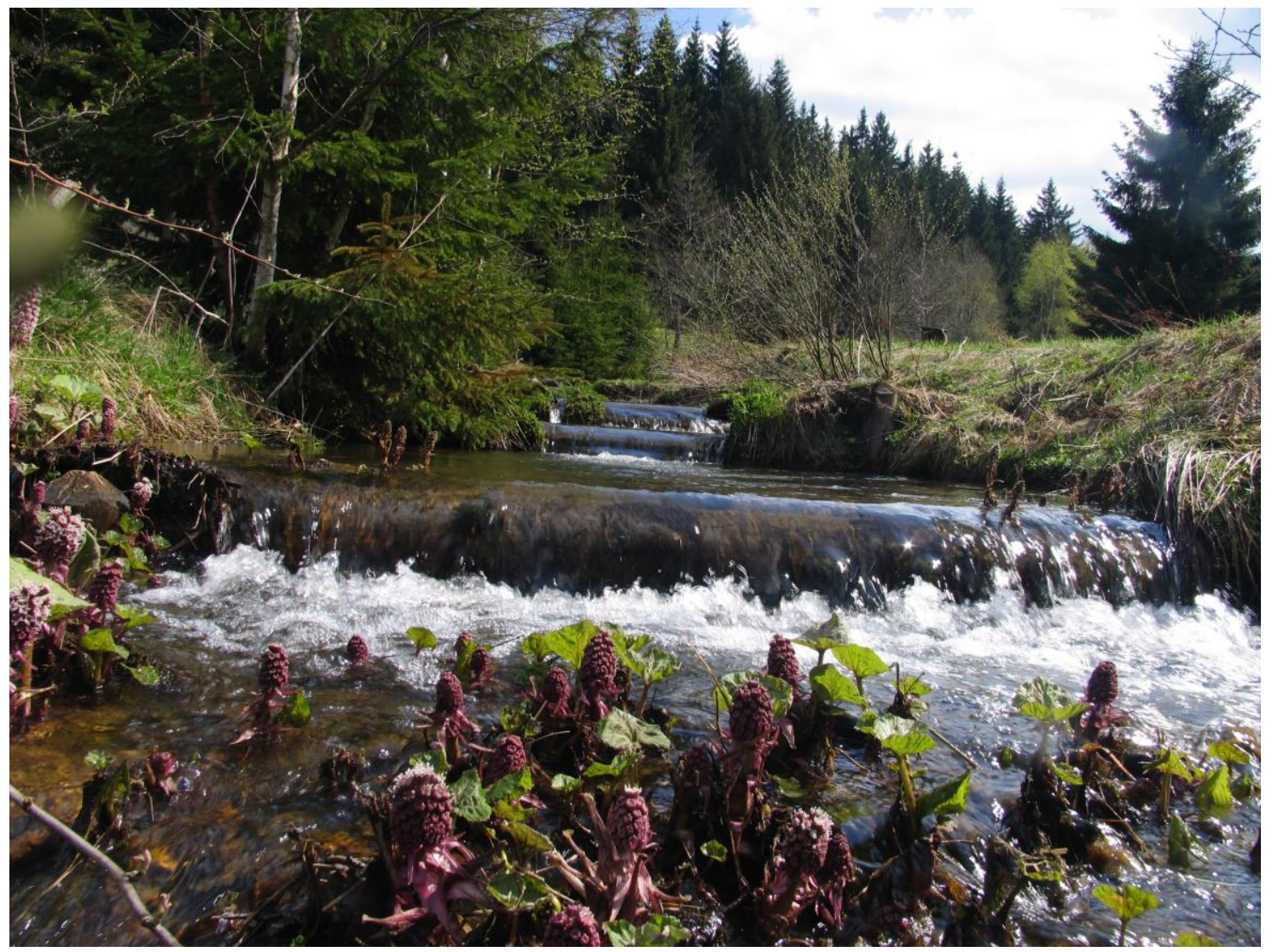

Fig 6: Zvonkové údolí valley between Nová Ves and Podlesí; alluvial forest biotopes with marshes and wet meadows allow mass occurence of horse flies. Photo by Josef Hájek. 


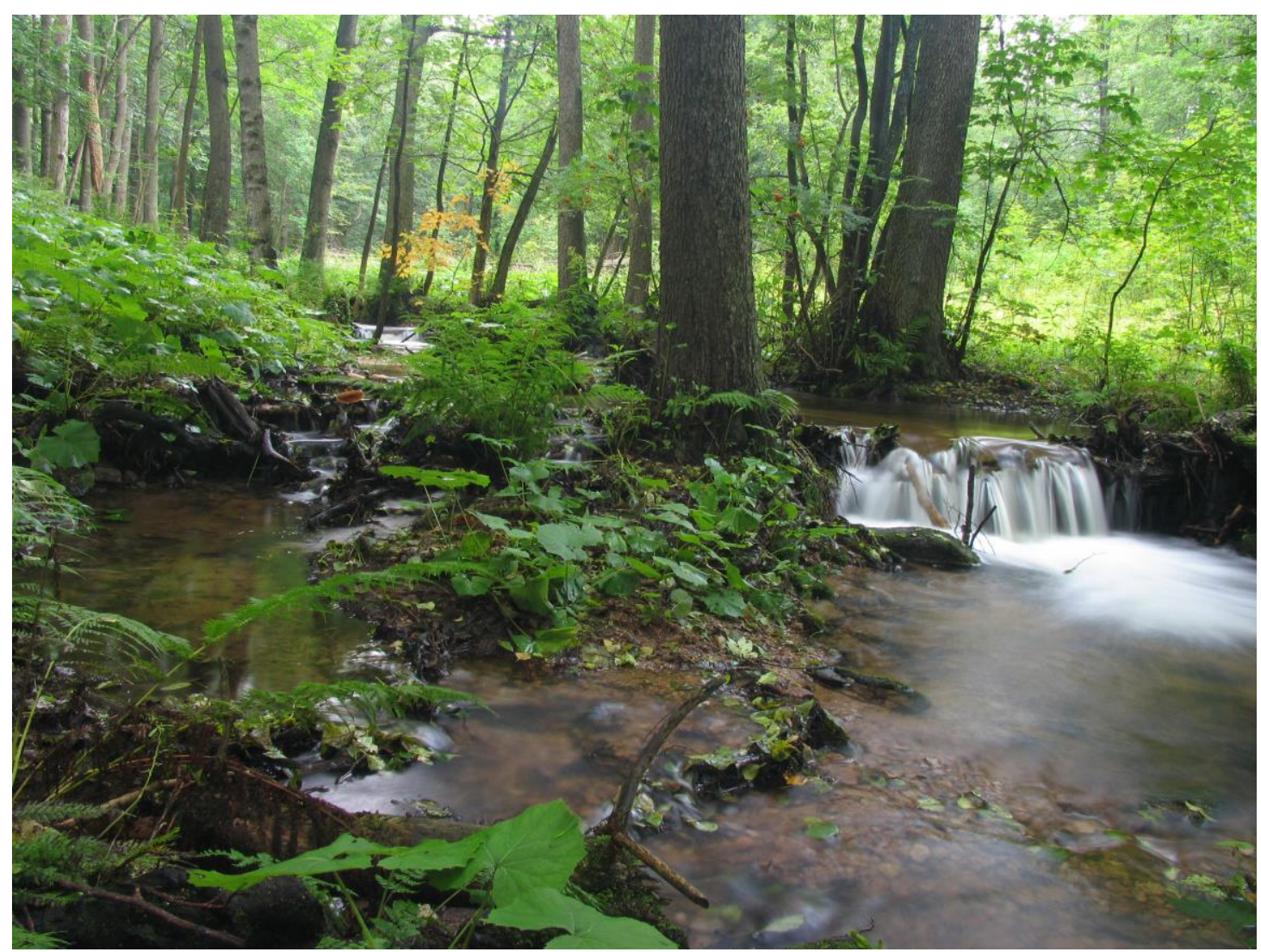

Fig 7: Between Vrchní Orlice and Hadinec; forest stream - suitable habitat for larvae of Chrysops caecutiens (L.). Photo by Josef Hájek.

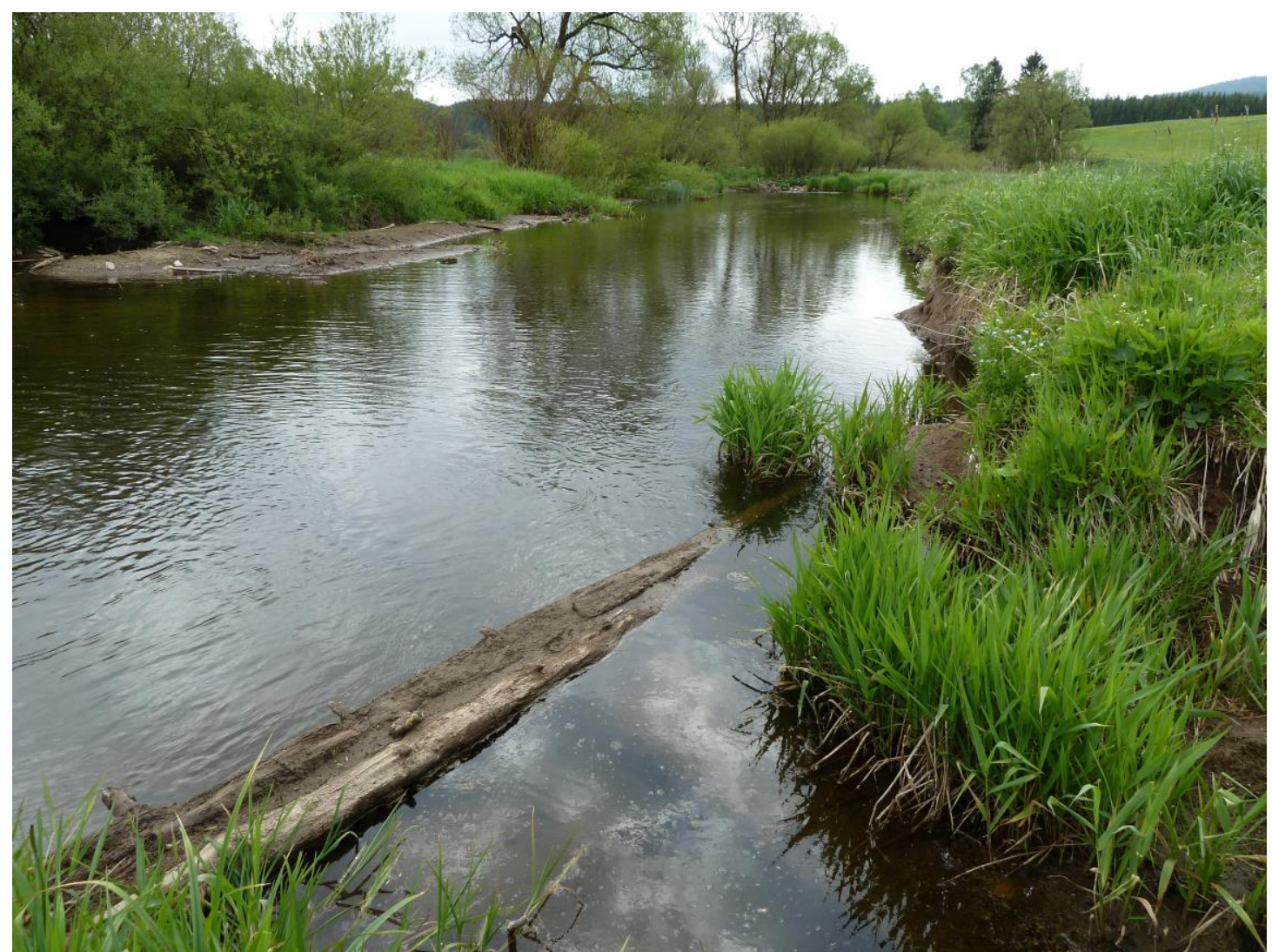

Fig 8: Orlické Záhoří environment; floodplain of the Divoká Orlice river, where larvae of Tabanus spp. can be collected. Photo by Josef Hájek. 
119. Uhersko - Lodrant pond NM (6062), Lodrantka brook, oak-hornbeam forest, deer park

120. U Kunštátské kaple chapel NM (5764), environs of Zdobnice, Orlické hory PLA, forest spring area, small brook near a deer-stand

121. Vamberk (5863), Zdobnice river, alluvial meadows, forests

122. Velká kotlina basin (5969) env. Vysoká hole Mt. (1464 m a.s.1.) and Praděd Mt. (1492 m a.s.1.), Jeseníky PLA

123. Velká louka meadow NM (5664), environs of Trčkov, Orlické hory PLA, forest margin, marshes, small artificial shot hole lakes, damp meadows

124. Vojtíškov (5867), environs of Hanušovice, meadows, pastures, small ponds, forests

125. Vrbno pod Pradědem (5870), Jeseníky PLA, small forest brook

126. Vrchní Orlice (5865), environs of Bartošovice v Orlických horách, Orlické hory PLA, valley of Divoká Orlice river, meadows, pastures, spring area, churchyard with collapsed walls, weekend cottages (Fig. 7)

127. Vysoká nad Labem $(5860,5861)$ near Hradec Králové, forests, swamps, small brooks, 240 m a.s.l.

128. Vysoká Srbská (5563), environs of Hronov, Židovka brook, forest, spring areas, $474 \mathrm{~m}$ a.s.l.

129. Vysoké Chvojno (5861), environs of Holice, Buky NR, a rest of the beech-fir primary forest, $296 \mathrm{~m}$ a.s.l.

130. Zdobnice (Velká Zdobnice in the past) (5764), Rychnov nad Kněžnou distr, Zdobnice river, $605 \mathrm{~m}$ a.s.1.

131. Zelenka (5764), between Bedřichovka and Jadrná, Orlické hory PLA, forest, cottages near road, small brook, swamps

132. Zelenka - U Čertova Mlýna meadow (5764), environs of Koruna Mt. (1099 m a.s.l.), Orlické hory PLA, forest slope swamp

133. Zemská brána (5865), between České Petrovice and Bartošovice v Orlických horách, Divoká Orlice river, Ledříčkova skála rock and Pašerácká lávka footbridge, Orlické hory PLA, forest, swamps, overhanging boughs, shore vegetation

134. Zlatý Potok (5966), environs of Králíky, tributary stream of Morava river, pastures, forest edge, $585 \mathrm{~m}$ a.s.1.

135. Zvonkové údolí valley (5765), between Nová Ves and Podlesí, Orlické hory PLA, forest openings, marshes, wet meadows, streams (Fig. 6)

136. Žamberk (5964); Divoká Orlice river, alluvial meadows, brooks, forest ponds, $418 \mathrm{~m}$ a.s.l.

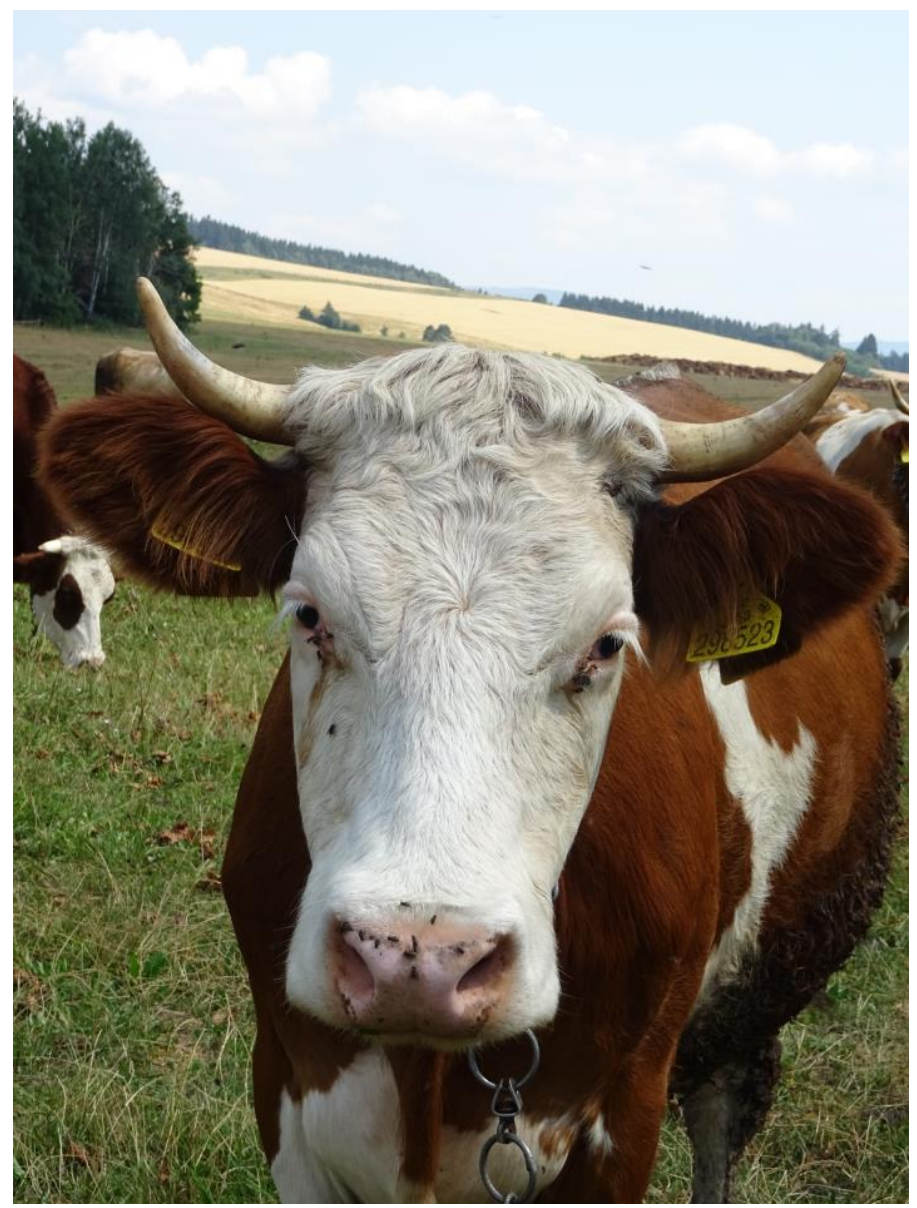

Fig 9: A foot-hill of Suchý vrch Mt. between Mladkov and Lichkov; a cattle-range vexed by Muscidae and often Tabanidae. Photo by Věra Ježková. 


\section{List of species}

\section{Chrysops caecutiens (Linnaeus, 1758)}

Published records. Moucha \& Chvála 1955, 1956a: Česká Třebová, Náchod, Ústí nad Orlicí; Moucha \& Chvála 1956a: Broumov, Hradec Králové; Formánek 1982: Bohdaneč.

Material examined. Adamovo jezero lake (1), 6.vii.2011, 7.vii.2012, $8 \mathrm{f}^{*} \mathrm{f}^{*}$, SW, J, NMPC; Bedřichovka (6), 25.vi.2003, $2 \mathrm{f}^{*} \mathrm{f}^{*}, \mathrm{MT}, \mathrm{H}, \mathrm{NMPC}$; Borohrádek (17), 3.vi.1978, 1 f*, SW, Mtj, MVCH; Černíkovice (24), 4.vi.2002, 1 f*, SW, J, NMPC; Dolní Čermná (33), 5.vii.2012, 1 f*, SW, J, NMPC; Hustířany (53), 30.v.2001, 1 f*, SW, Mo, MVCH; Klečkov - Poříčí (63), 27.vi.1994, 2 f*f*, SW, J, NMPC; Mělčany - Zlatý potok brook (73), 18.vi., 5. and 24.vii.2002, 34 f* $\mathrm{f}^{*}, 4 \mathrm{~m} * \mathrm{~m}^{*}$, MT, C, J, M, NMPC; Nová Ves env. Orlické Záhoří (80), 20.vii.2004, 18.vii.2006, $2 \mathrm{f}^{*} \mathrm{f}^{*}$, MT, H, NMPC; Trčkov NNR (116), 7.vi.2011, $31 \mathrm{f}^{*} \mathrm{f}^{*}, \mathrm{SW}, \mathrm{H}, \mathrm{J}, \mathrm{S}, \mathrm{NMPC}$ Trčkovská louka meadow (117), 20.viii.1996, 20.vii.2004, 2 f**, MT, H, NMPC; Zvonkové údolí valley (135), 25.vi.2003, $3 \mathrm{f}^{*} \mathrm{f}^{*}, \mathrm{MT}, \mathrm{H}, \mathrm{NMPC}$.

Comments. A Euro-Siberian species distributed from the Iberian Peninsula throughout Europe and the Mediterranean to the Russian Far East, Iran, China and Mongolia. Common species in forest regions from lowlands to mountains. Larvae are frequent in bottom of rills and brooks; pupae can be found in the soil of meander flows close to the surface.

\section{Chrysops relictus Meigen, 1820}

Published records. Vimmer 1913, Moucha \& Chvála 1956a: Česká Třebová, Hradec Králové; Formánek 1982: Bohdaneč.

Material examined. Broumarské slatiny swamps NM (18), 3.vi.2002, 1 f*, SW, J, NMPC; Častolovice (22), 5.vi.2002, 1 f*, SW, J, NMPC; Černíkovice (24), 4.vi.2002, 1 f*, SW, J, NMPC; Hradec Králové - Malšovice (48), 29.vii.1996, 1 f*, SW, Mo, MVCH; Lázně Bohdaneč - ponds (70), 7.viii.2001, 4. and 24.vi., 16.vii., 7.viii., 6.ix.2003, 23.vi., 7. and 16.vii., 3. and 18.viii.2004, 4. and 21.vii., 2. and 13.viii., 2.ix.2005, $70 \mathrm{f}^{*} \mathrm{f}^{*}, 12 \mathrm{~m} * \mathrm{~m}^{*}$, SW, MT, C, F, J, M, Mo, NMPC, MVCH; Mělčany - Zlatý potok brook (73), 18.vi.2002, 1 f*, MT, C, J, M, NMPC; Na Plachtě NM (75), 10.vi.1988, 1 f*, SW, Mo, MVCH; Prochody (93), 4.viii.1997, 1 f*, SW, J, NMPC.

Comments. A Euro-Siberian forest-steppe species widely distributed from the Iberian Peninsula and the British Isles throughout almost the whole of Europe to Eastern Siberia, China and Mongolia. It has been reported from lowlands and hilly regions. Larvae live in lentic water of ponds, shallow water reservoirs with soil bottom or in muddy grounds of slow flowing irrigation canals, brooks and rivers.

\section{Chrysops rufipes Meigen, 1820}

Published records. Vimmer 1913, Moucha \& Chvála 1956a, 1959c: Hradec Králové.

Comments. A European-Westsiberian forest-steppe species, known from the Netherlands, Belgium, France, Switzerland and North Italy to Altai and the Jenisej River, penetrates to the Scandinavian boreal bioregion and south to Bosnia, Romania and the Crimea. Larvae live in swampy meadows and watersides of reservoirs polluted by organic substances (stagnant water). Assessment of current conservation status in the Czech Republic: EN.

\section{Chrysops viduatus (Fabricius, 1794)}

Material examined. Broumarské slatiny swamps NM (18), 3.vi.2002, $7 \mathrm{f}^{*} \mathrm{f}^{*}$, SW, J, NMPC; Černíkovice (24), 4.vi.2002, 1 f*, SW, J, NMPC; České Meziř̌čči - Zbytka NR (30), 15.-22.vii.1996, 1 f*, MT, Mo, MVCH; Lázně Bohdaneč - ponds (70), 18.vii.1995, 7.viii.2001, 4. and 24.vi., 16.vii., 7.viii., 6.ix.2003, 4. and 23.vi., 4., 7. and 16.vii., 3. and 18.viii., 15.ix.2004, 9.vi., 4., 13. and 21.vii., 13.viii.2005, $249 \mathrm{f}^{*} \mathrm{f}^{*}, 14 \mathrm{m*} \mathrm{m}^{*}$, MT, SW, C, F, J, M, Mo, NMPC, MVCH; Mělčany - Zlatý potok brook (73), 18.vi., 5. and. 24.vii., 6.viii.2002, 233 f***, MT, C, J,

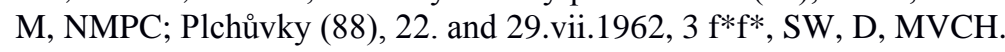

Comments. Widely distributed from Europe to Western Siberia, Balkan Peninsula, including some Mediterranean islands, Turkey. Immature stages develop in swampy and marshy habitats (e.g. alder forests). 


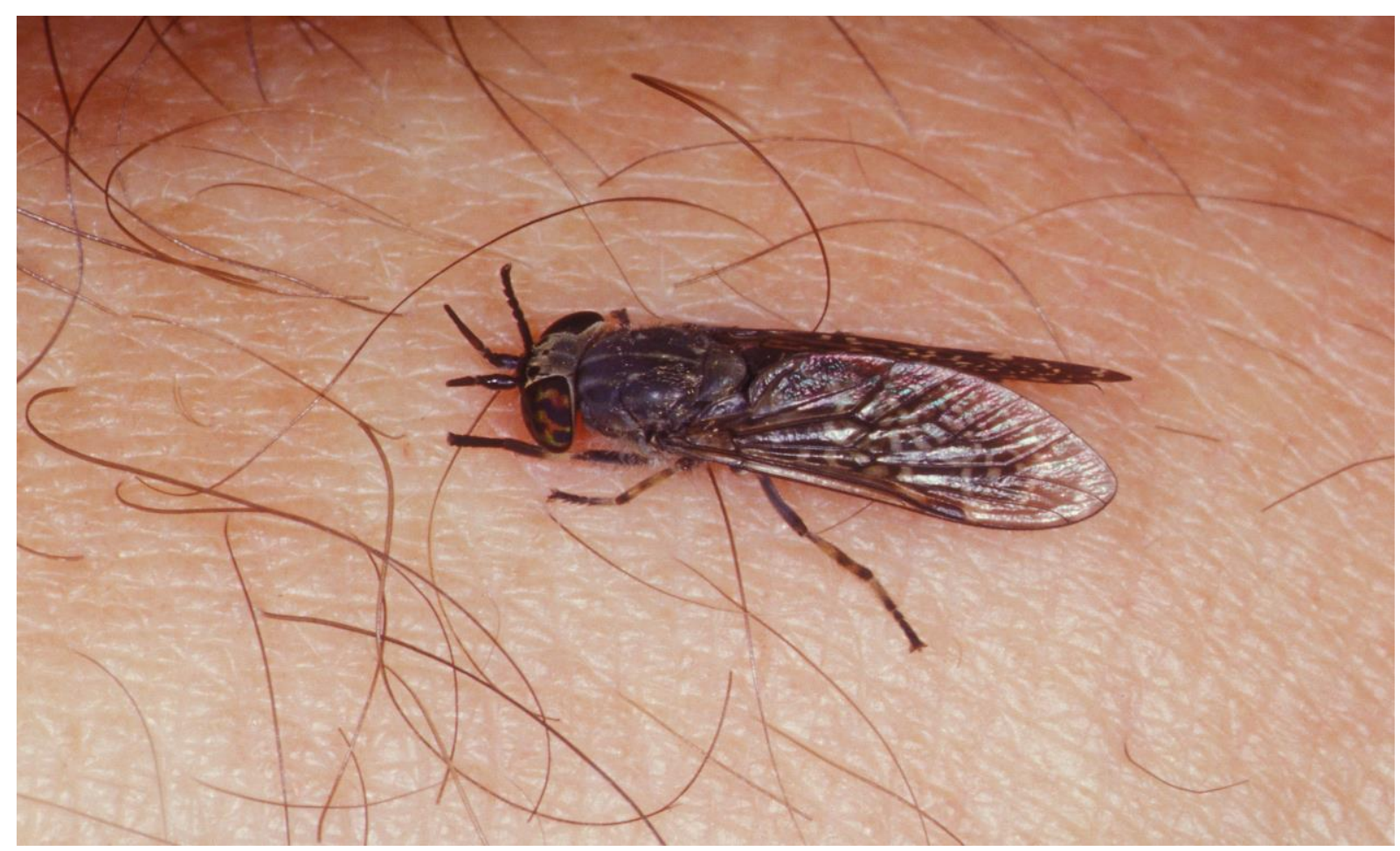

Fig 10: Haematopota pluvialis (L.) - female; supposed to be a vector of tularemia and anthrax. Photo by Miroslav Kopeček.

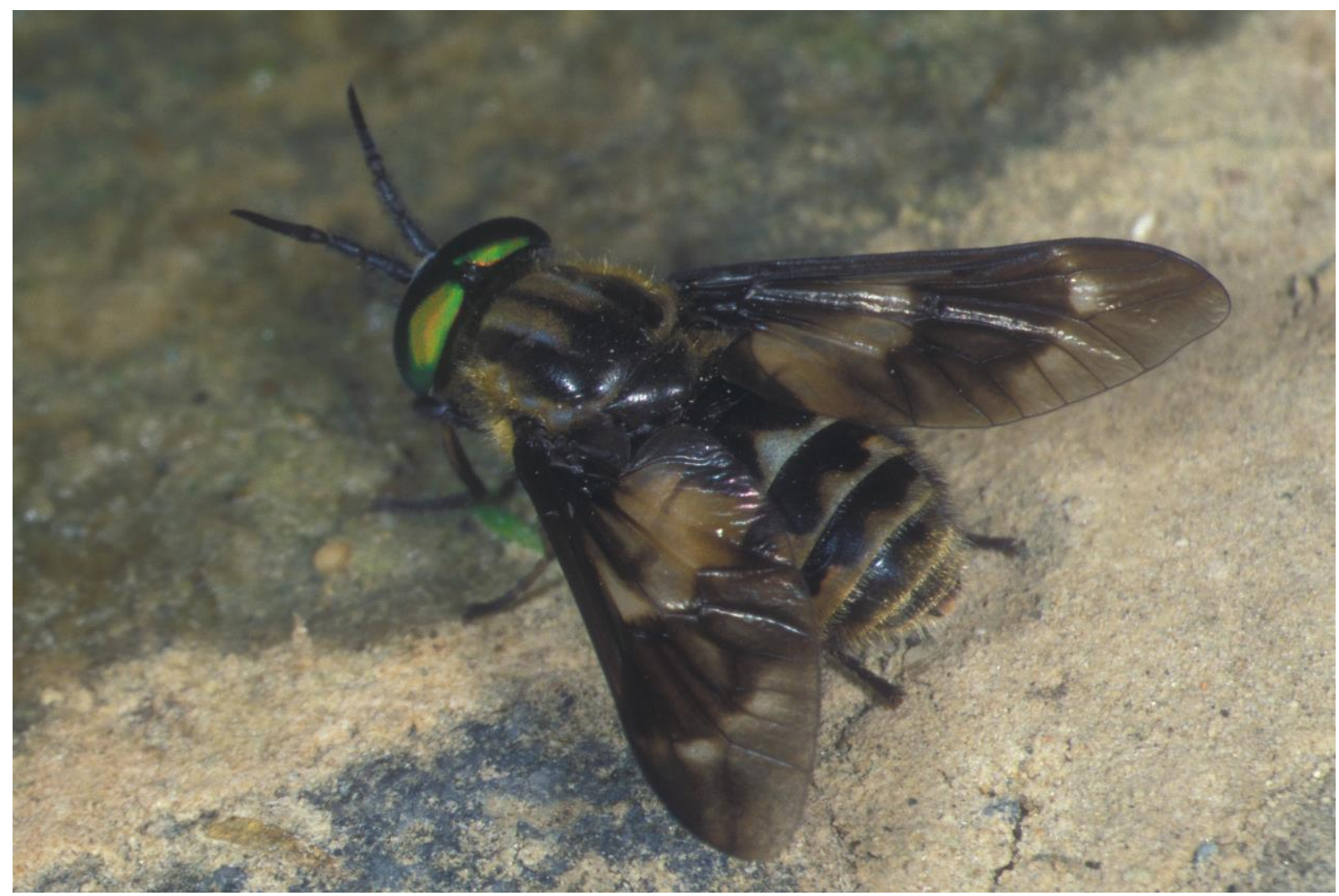

Fig 11: Chrysops relictus Meig. - male; larvae live in lentic water of ponds. Photo by Miroslav Kopeček. 


\section{Silvius alpinus (Scopoli, 1763)}

Published records. Vimmer 1913, Moucha \& Chvála 1956a: Česká Třebová, Hradec Králové.

Material examined. Koruna (64), 17.vii.2014, 2 f*f*, SW, Je, Ma, NMPC.

Comments. Distributed in southern and central Europe, Ural, Transcaucasus and Turkey; localities published from North Africa still need to be verified. Always collected in low numbers. In Bohemia rather rare (see Ježek \& Ježková 1978). The larvae are known from small muddy rivers, springs, banks of water reservoirs, and alluvial plant and wood deposits. Assessment of the current conservation status in the Czech Republic: NS.

\section{Atylotus plebejus (Fallén, 1817)}

Published record. Ježková 1974: Velké Losiny.

Material examined. Broumarské slatiny swamps NM (18), 24.vii.1962, 1 f*, SW, Ce, MVCH.

Comments. Known from the British Isles and Scandinavia as far as the Far East of Russia and North East of China. The south border of its distribution in Europe is limited by Bayern, Austria, Czech Republic and Slovakia. The larvae inhabit peatbogs. Assessment of the current conservation status in the Czech Republic: EN.

\section{Atylotus rusticus (Linnaeus, 1767)}

Published records. Czižek 1908, Moucha \& Chvála 1956c: Velké Losiny - valley of Desná river; Vimmer 1913, Moucha \& Chvála 1956a: Česká Třebová; Moucha \& Chvála 1956a, 1969: Hradec Králové; Moucha \& Chvála 1961: Nové Město nad Metují; Moucha \& Chvála 1969: Velký Vřešt'ov; Ježková 1974: Piletice, Věkoše.

Material examined. Hradec Králové - Nový Hradec Králové (49), 10.viii.1956, 1 f*, SW, Z, MVCH.

Comments. A common species in the past, widely distributed throughout Europe and Siberia, to North Africa and Turkey. It is usually collected in agricultural landscapes.

\section{Glaucops hirsutus (Villers, 1789)}

Published records. Ježková 1974: Malá Morávka; Chvála 1980: Karlova Studánka.

Comments. Very rare European species of mountain peatbogs: France, Switzerland, Austria, Czech Republic and Poland. Sometimes only locally common, see Dvořák (2011b, p. 46) and Ježek et al. (2012, p. 177). Assessment of the current conservation status in the Czech Republic: VU.

\section{Hybomitra arpadi (Szilády, 1923)}

Material examined. Trčkov NNR (116), 7.vi.2011, 1 f*, SW, H, J, S, NMPC.

Comments. A Holarctic species of tree line and taiga, present over much of the north-eastern regions of Eurasia (from Scandinavia to Far East, China and Japan) with the southern limit of the distribution passing through Belgium, Germany, Czech Republic (new localities see Dvořák 2011a and Ježek et al. 2012), Poland, Lithuania and Central European Russia (Moscow Region). The Nearctic range is transcontinental and extends to New England and Minnesota (Teskey 1990). Larvae inhabit shaded swamps and peat bogs, and littoral zones of small forest water reservoirs (Ježek 1977a). Assessment of the current conservation status in the Czech Republic: NS.

\section{Hybomitra auripila (Meigen, 1820)}

Published records. Czižek 1907, Moucha \& Chvála 1956c, 1959a, 1968: Praděd; Czižek 1908, Landrock 1932, Moucha \& Chvála 1956c: Jeseníky; Moucha \& Chvála 1959b, 1968: Hradec Králové; Moucha \& Chvála 1961: Velký Kotel - Jeseník; Moucha \& Chvála 1968: Karlova Studánka, Petrovy Kameny; Ježková 1974: Horní Lipka, Karlov, Vřesová studánka.

Material examined. Bartošovice v Orlických horách (5), 29.vi.-18.vii.1994, 2 f*f*, YPT, H, J, NMPC; 
Bedřichovka (6), 23.vii.2003, vii.2007, 11 f*f*, MT, H, NMPC; Bukačka NNR (20), 10.vii.1991, 20.-29.vi. and 28.vi.-18.vii.1994, 22.vii.2009, 7.vi.2011, 12 f*f*, 3 m*m*, SW, YPT, H, J, Mo, Va, NMPC, MVCH; Černý důl valley (25), 10.vii.1995, 1 f*, YPT, H, NMPC; Ćíhalka - Vápenka (31), 26.vi.1994, 1 f*, SW, J, NMPC; Dolní Morava (36), 19.vii.2006, 1 f*, SW, J, NMPC; Horní Lipka (44), 12.vi.1972, 1 f*, SW, J, NMPC; Horní Morava - Zátiší (45), 14.vii.2001, 1 f*, SW, J, NMPC; Hořečky NR (47), 9.vi.2009, 2 f*f*, SW, H, NMPC; Jelení lázeň peatbog NR (56), 17.vi.1996, 8.vii.1981, 2 f*f*, SW, JiH, Mo, NMPC, MVCH; Jetřichov (57), 22.v.1997, 1 m*, SW, J, NMPC; Klečkov - Poříčí (63), 27.vi.1994, 1 f*, SW, J, NMPC; Nebeská Rybná (76), 26.vi.2002, 2 f***, SW, H, NMPC; Neratov (78), 10.vi.1998, 2 f*f*, SW, H, NMPC; Nová Ves env. Orlické Záhoří (80), 11.vi.1996, 1 f*, SW, JiH, NMPC; Orlické Záhoří (82), 29.vi.1994, 4 f*f*, SW, J, NMPC; Ošerov (84), 8.vi.2011, 3 f***, SW, J, NMPC; Pěticestí crossway (87), 11.vi.1996, 2 f**, SW, JiH, NMPC; Podlesí (89), 12.vi.2007, 1 f*, SW, H, NMPC; Pod Sfingou NM (90), 10.vii.1995, 22.vii.2003, 3 f***, MT, YPT, H, P, NMPC; Pod Zakletým NR (91), 31.vii.1995, 4 f*f*, YPT, H, NMPC; Prudký potok brook - Mokřiny (95), 19.vii.2005, 1 f*, SW, J, NMPC; Rašeliniště Kačerov NR peatbog (98), 18.vi.1996, 2 f*f*, SW, JiH, NMPC; Rožmitál env. Broumov (101), 25.vi.2015, 1 f*, SW, Mo, MVCH; Šerlich Mt. (112), 8.vi.2011, 1 f*, SW, J, NMPC; Špičák quarry near Plasnice (114), 8.vi.2011, 10 f*f*, SW, J, NMPC; Trčkov NNR (116), 17.vi.2003, 11.vi.2007, 7.vi.2011, 56 f*f*, SW, H, J, S, NMPC; U Kunštátské kaple chapel NM (120), 17.vi.1996, 1 f*, SW, JiH, NMPC; Velká kotlina basin (122), 30.vi.1977, 1 f*, SW, R, PFMU; Velká louka meadow NM (123), 19.vi.2002, 5 f*f*, SW, H, NMPC; Vojtíškov (124), 13.vi.2005, 1 f*, SW, J, NMPC; Zemská brána (133), 19.vi.2003, 1 f*, SW, H, NMPC; Zvonkové údolí valley (135), 21.vii.2003, 1 f*, MT, H, NMPC.

Immature stages. Velká louka meadow NM (123), 2 f*** ex larva collected 6.v.1999, H, J, eclosion v.1999, exuviae of larvae and pupae are deposited in the eth./coll. NMPC n. 31, 32; Zvonkové údolí valley (135), 1 f* ex larva collected 20.iv.1999, H, J, eclosion v.1999, exuviae of larvae and pupa in the eth./coll. NMPC n. 1.

Comments. A European species occupies mainly hilly and mountain areas, known from Pyrenees to the Carpathian mountains, recorded from all parts of Alps. Northern border of distribution lies in Scandinavia. Larvae are known from swamps near wood edges, wet meadows, peatbogs and moorlands.

\section{Hybomitra bimaculata (Macquart, 1826)}

Published records. Moucha \& Chvála 1968, Formánek 1982: Bohdaneč.

Material examined. Bedřichovka (6), vii.2007, 4 f*f*, MT, H, NMPC; Broumarské slatiny swamps NM (18), 3.vi.2002, $14 \mathrm{f}^{*} \mathrm{f}^{*}$, SW, J, NMPC; Černíkovice (24), 4.vi.2002, $2 \mathrm{f}^{*} \mathrm{f}^{*}$, SW, J, NMPC; Černý potok brook (26), 23.vi.2005, 1 f*, MT, H, NMPC; Červený Potok (28), 30.v.2003, 1 f*, SW, J, NMPC; České Meziříčí - Zbytka NR (30), 15.-22.vii.1996, 1 f*, MT, Mo, MVCH; Lázně Bohdaneč - ponds (70), 11.vii.1985, 4.vi.2003, 4.v., 4.vi and 23.vi., 3.viii. 2004, 16.v., 9.vi. and 4.vii.2005, $134 \mathrm{f}^{*} \mathrm{f}^{*}, 1 \mathrm{~m}^{*}$, MT, SW, C, J, M, Mo, NMPC, MVCH; Mělčany - Zlatý potok brook (73), 27.v., 18.vi., 5.vii.2002, 5 f*f*, MT, C, J, M, NMPC; Nebeská Rybná (76), 26.vi.2002, 2 f***, SW, H, NMPC; Orlické Záhoří (82), 29.vi.1994, 3 f*f*, SW, J, NMPC; Podlesí (89), 12.vi.2007, 5 f*f*, SW, H, NMPC; Rašeliniště Kačerov NR peatbog (98), 10.vi. and 14.vii.1998, 4 f*f*, SW, MT, H, J, NMPC; Rožmitál env. Broumov (101), 2.vi.2000, 1 f*, SW, Mo, MVCH; Sítovka NM (106), 26.vi.1991, 1 f*, SW, Mo, MVCH; Trčkov NNR (116), vi.1997, 12.vii.2005, 4 f*f*, MT, SW, H, J, P, S, NMPC; Vrchní Orlice (126), 15.vii.2010, 2 f*f*, SW, H, NMPC; Zemská brána (133), 19.vi.2003, 1 f*, SW, H, NMPC.

Immature stages. Rašeliniště Kačerov NR peatbog (98), 1 f* ex larva collected 12.iv.2005, H, J, NMPC; eclosion 4.v.2005, exuvia of larva damaged, exuvia of pupa pinned.

Comments. Widespread in the Palaearctic Region, very common. Larvae have been found in the littoral of ponds, lakes, artificial water reservoirs, slow-flowing drainage canals, forest swamps and wet meadows.

\section{Hybomitra bimaculata f. bisignata (Jaennicke, 1866)}

Material examined. Lázně Bohdaneč - ponds (70), 4.vi.2003, 9.vi.2005, 3 f*f*, MT, SW, J, Mo, NMPC; Mělčany - Zlatý potok brook (73), 18.vi.2002, 1 f*f*, MT, C, J, M, NMPC.

Comments. Widespread in the Palaearctic Region, always rare. The larvae were found in the littoral zone of natural or artificial water reservoirs, irrigational canals, forest marshes and damp meadows. 


\section{Hybomitra ciureai (Séguy, 1937)}

Published record. Formánek 1982: Bohdaneč.

Material examined. Lázně Bohdaneč - ponds (70), 4. and 24.vi., 16.vii.2003, 4. and 23.vi.,7. and 16.vii., 3. and 18.viii.2004, 4., 13. and 21.vii.2005, $45 \mathrm{f}^{*} \mathrm{f}^{*}, 1 \mathrm{~m} *$, MT, SW, C, J, M, Mo, NMPC.

Comments. A Euro-Siberian, widely distributed forest-steppe species. Larvae have been found in the littoral zone of forest water reservoirs, muddy meander rivers and inundated wet meadows (Chvála \& Ježek 1969).

\section{Hybomitra distinguenda (Verrall, 1909)}

Published records. Moucha \& Chvála 1959b, 1968: Hradec Králové; Ježková 1974: Horní Lipka, Nové Město nad Metují, Suchý vrch env. Jablonné nad Orlicí, Uhersko, Karlova Studánka; Formánek 1982: Bohdaneč.

Material examined. Adamovo jezero lake (1), 6.vii.2011, 7.vii.2012, 31 f*f*, SW, J, NMPC; Antoniino údolí valley (4), 17.vi.2003, 11.vi.2007, 7 f* $f^{*}$, SW, H, NMPC; Bartošovice v Orlických horách (5), 20.-29.vi.1994, 29.vi.-18.vii.1994, 3 f* $\mathrm{f}^{*}$, YPT, H, J, P, Va, NMPC; Bedřichovka (6), vii.2007, $3 \mathrm{f}^{*} \mathrm{f}^{*}, \mathrm{MT}, \mathrm{H}$, NMPC; between Pasínky and Bystřina (11), 31.vii.2001, 1 f*, SW, J, NMPC; Broumarské slatiny swamps NM (18), 3.vi.2002, 1 f*, SW, J, NMPC; Bukačka NNR (20), 28.vi.-18.vii.1994, 2 f*f*, YPT, H, Va, NMPC; Buková hora Mt. (21), 12.vii.2006, $3 \mathrm{f}^{*} \mathrm{f}^{*}$, SW, J, NMPC; Červená Voda (27), 16.vii.2006, 1 f*, SW, J, NMPC; Dolní Čermná (33), 31.vii.1978, $5 \mathrm{f}^{*} \mathrm{f}^{*}$, SW, J, NMPC; Dolní Morava (36), 19.vii.2006, $2 \mathrm{f}^{*} \mathrm{f}^{*}$, SW, J, NMPC; Heřmanice (41), 10.vii.2001, 1 f*, SW, J, NMPC; Horní Morava - Zátiší (45), 14.vii.2001, 4 f*f*, SW, J, NMPC; Jablonné nad Orlicí (54), 11.vii.1981, 1 f*, SW, J, NMPC; Jadrná (55), 3.vii.1998, 2 f*f*, SW, H, NMPC; Karlova Studánka (62), 4.-5.vii.1968, 4 f*f*, SW, J, NMPC; Klečkov - Poříčí (63), 27.vi.1994, 4 f*f*, SW, J, NMPC; Lázně Bohdaneč - ponds (70), 4.vi.2003, 1 f*, SW, J, NMPC; Mělčany - Zlatý potok brook (73), 18.vi.2006, 1 f*, 1 m*, MT, C, J, M, NMPC; Nebeská Rybná (76), 26.vi.2002, 1 f*, SW, H, NMPC; Nepomuky (77), 12.vii.1981, 2 f*f*, SW, J, NMPC; Neratov (78), 10.vi.1998, 1 f*, SW, H, NMPC; Orlické Záhoří (82), 29.vi. 1994, 2 f*f*, SW, J, NMPC; Ošerov (84), 9.vii.2008, 1 f*, ET, H, NMPC; Pěticestí crossway (87), 11.vi.1996, 3 f*f*, SW, JiH, NMPC; Podlesí (89), 12.vi.2007, 19 f*f*, SW, H, NMPC; Pod Sfingou NM (90), 22.vii.2003, 4 f*f*, MT, H, NMPC; Pod Zakletým NR (91), 31.vii.1995, 3 f***, YPT, H, NMPC; Rašeliniště Kačerov NR peatbog (98), 1.viii.1993, 18.vi. 1996, 11.vii.2008, 4 f* $\mathrm{f}^{*}$, SW, MT, H, J, JiH, NMPC; Ruské údolí valley near Olešnice v Orlických horách (103), 7.vii.1981, 1 f*, SW, Mo, MVCH; Selské vrchy hills - Mlýnský potok brook (105), 29.vi.2001, 1 f*, MT, Ve, NMPC; Sopotnice - Pod horou (109), 8.viii.-13.viii.1999, 1 f*, MB, H, NMPC; Suchý vrch Mt. (111), 8.vii.1968, 2 f*f*, SW, J, NMPC; Šerlich Mt. (112), 10.vii.1981, 1 f*, SW, Mo, MVCH; Špičák quarry near Plasnice (114), 8.vi.2001, $2 \mathrm{f}^{*} \mathrm{f}^{*}$, SW, J, NMPC; Trčkov NNR (116), 29.vi.-18.vii.1994, 17. and 25.vi.2003, 11.vi.2007, 7.vi.2011, 20 f*f*, SW, MT, H, J, S, Va, NMPC; Uhersko - Lodrant pond NM (119), 2.vii.1967, 1 f*, SW, Ho, NMPC; Velká louka meadow NM (123), 19.vi.2002, 1 f*, SW, H, NMPC; Zelenka (131), 22.vii.2009, 1 f*, MT, H, NMPC; Zelenka - U Čertova Mlýna meadow (132), 16.-29.vi.1994, 1 f*, YPT, H, Va, NMPC; Zemská brána (133), 19.vi.2003, 16 f***, SW, H, NMPC; Zvonkové údolí valley (135), 21.vii.2003, 2 f*f*, MT, H, NMPC.

Immature stages. Rašeliniště Pod Předním vrchem peatbog (99), 4 f*f* ex larva collected 21.iv.1999, H, J; eclosion v.1999, exuviae of larvae and pupae in the eth./coll. NMPC n. 4, 9-10, 22. Trčkov NNR (116), 4 f*f* ex larva collected 19.-22.iv.1999, H, J; eclosion v.1999, exuviae of larvae and pupae in the eth./coll. NMPC n. 1213, 16-17. Same (116), 7 f*f* ex larva collected 3.-4.v.1999, H, J; eclosion v.1999, exuviae of larvae and pupae in the eth./coll. NMPC n. 25, 49, 59-60, 160, 163, 186. Vrchní Orlice (126), 1 f* ex larva collected 5.v.1999, H, $\mathrm{J}$; eclosion v.1999, exuviae of larva and pupa in the eth./coll. NMPC n. 27. Zelenka (131), $1 \mathrm{f} *$ ex larva collected 21.iv.1999, H, J, eclosion v.1999; exuviae of larva and pupa in the eth./coll. NMPC n. 35.

Comments. A Palaearctic forest species distributed throughout Europe and Asia including Far East, Japan, China and Mongolia; also known from Morocco (Ježek 1995). Larvae inhabit the littoral zones of forest ponds, floating peat moss and peaty lake margins, marshy swamps of lowlands and hilly regions.

\section{Hybomitra kaurii Chvála \& Lyneborg, 1970}

Material examined. Bukačka NNR (20), 7.vi.2011, 1 f*, SW, J, NMPC; Velká louka meadow NM (123), 19.vi.2002, 1 f*, SW, H, NMPC.

Comments. A widely distributed species (but rather rare) from Scandinavia as far as to Kamtchatka, south border of its distribution in Asia is limited by Altai, North Mongolia and China. Recorded from French, Swiss, Italian and Austrian Alps. Also collected in large pond 
basin in the South of Bohemia and Carpathians in Slovakia. Assessment of the current conservation status in the Czech Republic: NS.

\section{Hybomitra lundbecki Lyneborg, 1959}

Published records. Moucha \& Chvála 1968: Hradec Králové, Králický Sněžník, Nové Město nad Metují; Ježková 1974: Horní Lipka, Karlov, Karlova Studánka; Formánek 1982: Bohdaneč.

Material examined. Between Karlova Studánka and Praděd Mt. (10), 2.vii.1968, 1 f*, SW, J, NMPC; Dolní Morava (36), 29.v.2003, 1 f*, SW, J, NMPC; Horní Lipka (44), 12.vi.1972, 7 f*f*, SW, J, NMPC; Karlov pod Pradědem (61), 6.vii.1968, 1 f*, SW, J, NMPC; Podlesí (89), 12.vi.2007, 1 f*, SW, H, NMPC; Trčkov NNR (116), 11.vi.2007, 7.vi.2011, 25 f*f*, SW, H, J, S, NMPC; Třesice (118) 1.vi.1960, 1 f*, SW, ? leg., MVCH; Velká louka meadow NM (123), 19.vi.2002, 1 f*, SW, H, NMPC.

Comments. A species known throughout almost the entire Palaearctic Region from Spain as far to the Far East; Korea, Japan, Mongolia and North East China. The south border of its distribution is limited by Balkan and Apennines. Very common in forests near lakes and ponds.

\section{Hybomitra lurida (Fallén, 1817)}

Published records. Moucha \& Chvála 1959b, 1968: Orlické hory; Formánek 1982: Bohdaneč.

Comments. A Holarctic psychrophile species distributed from the British Isles to Siberia, Kamtchatka, Japan and North America. The south line of its distribution is limited by France, Bavaria, Bohemia, Moravia, Slovakia, Hungary and Ukraine. In Europe it occupies especially peatbogs and moorland biotopes. Assessment of the current conservation status in the Czech Republic: NS.

\section{Hybomitra micans (Meigen, 1804)}

Published records. Landrock 1907, 1932, Moucha \& Chvála 1956c, 1959b, 1968: Svitavy; Moucha \& Chvála 1959b, 1968: Králický Sněžník; Moucha \& Chvála 1968: Ramzová, Šerák; Ježková 1974: Horní Lipka, Karlov, Karlova Studánka, Praděd.

Material examined. Anenský vrch Mt. (3), 26.vi.2008, 2 f***, MT, H, NMPC; Bedřichovka (6), 25.vi.2003,

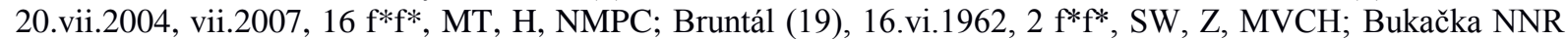
(20), 20.-29.vi.1994, 22.vii.2009, 7.vi.2011, 3.vi.2012, $31 \mathrm{f}^{*} \mathrm{f}^{*}, 3 \mathrm{~m} * \mathrm{~m} *$, MT, SW, YPT, H, J, Va, NMPC; Černý důl valley (25), 10.vii.1995, 1 f*, YPT, H, NMPC; Červený Potok (28), 30.v.2003, 1 f*, SW, J, NMPC; Dolní Morava (36), 29.v.2003, $4 \mathrm{f}^{*} \mathrm{f}^{*}$, SW, J, NMPC; Horní Lipka (44), 12. and 19.vi.1972, $14 \mathrm{f}^{*} \mathrm{f}^{*}, 1 \mathrm{~m} *$, SW, J, NMPC; Hořečky NR (47), 9.vi.2009, 9 f***, SW, H, NMPC; Jadrná (55), 3.vii.1998, 1 f*, SW, H, NMPC; Jelení lázeň peatbog NR (56), 17.vi.1996, 1 f*, SW, JiH, NMPC; Karlov pod Pradědem (61), 22.vi.1972, 2 f***, SW, R, NMPC and PFMU; Králický Sněžník Mt. (66), vii.2003, 1 f*, MT, C, J, M, NMPC; Králický Sněžník Mts. - U strašidel timber chalet (67), 29.v.1999, 1 f*, SW, J, NMPC; Neratov (78), 10.vi.1998, 2 f* $\mathrm{f}^{*}, \mathrm{SW}, \mathrm{H}, \mathrm{NMPC}$; Ošerov (84), 25.v., 24. and 26.vi.2008, 8.vi.2011, $12 \mathrm{f}^{*} \mathrm{f}^{*}, 4 \mathrm{~m} * \mathrm{~m}^{*}$, SW, ET, H, J, NMPC; Pěticestí crossway (87), 11.vi.1996, 1 f*, SW, JiH, NMPC; Podlesí (89), 12.vi.2007, 4 f***, SW, H, NMPC; Pod Sfingou NM (90), 25.vi., 22.vii.2003, 4 f***, MT, H, NMPC; Prudký potok brook - Mokřiny (95), 4.vii.2005, 1 f*, SW, J, NMPC; Rožmitál env. Broumov (101), 21.v.2009, 3.vi.2015, $2 \mathrm{f}^{*} \mathrm{f}^{*}, 1 \mathrm{~m} *$, SW, Mo, MVCH; Šerlich Mt. (112), 29.vi.1994, 8.vi.2011, 26 f*f*, SW, J, NMPC; Šerlišský Mlýn hostel (113), 9.vi.1998, 1 f*, SW, H, NMPC; Špičák quarry near Plasnice (114), 8.vi.2001, 7 f* $\mathrm{f}^{*}$, SW, J, NMPC; Trčkov NNR (116), 20.viii.1996, 30.vi.1999, 17. and 25.vi.2003, 11.vi.2007, 7.vi.2011, 99 f***, MT, SW, MB, H, J, S, NMPC; Velká louka meadow NM

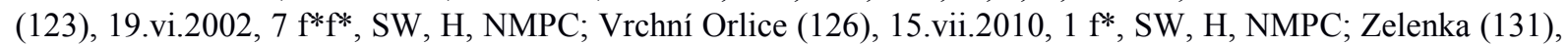
1. and 22.vii.2009, $3 \mathrm{f}^{*} \mathrm{f}^{*}$, MT, H, NMPC; Zvonkové údolí valley (135), 25.vi.2003, $4 \mathrm{f}^{*} \mathrm{f}^{*}, 1 \mathrm{~m} *$, MT, H, NMPC.

Immature stages. Jadrná (55), 1 m* ex larva collected 22.iv.1999, H, J; eclosion v.1999, exuviae of larva and pupa in the eth./coll. NMPC n. 2.

Comments. A European species known from the Iberian Peninsula throughout the British Isles and countries near North Sea, Central Europe and northern Apennines and the Balkans. Immature stages inhabit mostly forest biotopes (marshes and peat bogs) from lowlands to mountains. 


\section{Hybomitra montana Meigen, 1820}

Published records. Landrock 1907, 1932, Moucha \& Chvála 1956c: Svitavy.

Material examined. Broumarské slatiny swamps NM (18), 3.vi.2002, 1 f*, SW, J, NMPC; Černíkovice (24), 4.vi.2002, 1 f*, SW, J, NMPC; Červený Potok (28), 30.v.2003, 1 f*, SW, J, NMPC; Dolní Morava (36), 29.v.2003, 1 f*, SW, J, NMPC; Jadrná (55), 3.vii.1998, 3 f***, SW, H, NMPC; Selské vrchy hills - Mlýnský potok brook (105), 29.vi.2001, 1 f*, MT, Ve, NMPC; Zvonkové údolí valley (135), 25.vi.2003, 1 f*, MT, H, NMPC.

Comments. A Palaearctic species distributed from the British Isles and Spain through Siberia as far as Kamtschatka, Sakhalin, Korea and Japan. Not quite frequent in the Czech Republic. The species inhabits the same biotopes as reddish Hybomitra species: mainly forest-steppe and taiga swamps of higher altitudes.

\section{Hybomitra muehlfeldi (Brauer, 1880)}

Published records. Moucha \& Chvála 1968, Formánek 1982: Bohdaneč.

Material examined. Adamovo jezero lake (1), 6.vii.2011, 7.vii.2012, $3 \mathrm{f}^{*} \mathrm{f}^{*}$, SW, J, NMPC; Broumarské slatiny swamps NM (18), 3.vi.2002, $2 \mathrm{f}^{*} \mathrm{f}^{*}$, SW, J, NMPC; Dolní Morava (36), 19.vii.2006, 1 f*, SW, J, NMPC; Lázně Bohdaneč - ponds (70), 23.v.1996, 7.viii.2001, 4. and 24.vi., 16.vii. and 7.viii.2003, 4. and 23.vi., 7.vii. and 3.viii.2004, 9.vi., 4. and 21.vii.2005, 147 f*f*, MT, SW, C, F, J, M, Mo, NMPC, MVCH; Mělčany - Zlatý potok brook (73), 18.vi.2002, 1 f*, MT, C, J, M, NMPC; Trčkov NNR (116), 17.vi.2003, 1 f*, SW, H, NMPC; Velká louka meadow NM (123), 19.vi.2002, 1 f*, SW, H, NMPC.

Comments. A Palaearctic species known from the British Isles as far as Chukotka Peninsula, in Europe penetrates from Scandinavia to the Mediterranean Sea. Rather lowland and hilly species, larvae inhabit wet meadows, banks of drainages, gutters and small forest ponds.

\section{Hybomitra nitidifrons confiformis Chvála \& Moucha, 1971}

Material examined. České Meziř́čí - Zbytka NR (30), 18.vi.1996, 1 f*, SW, Mo, MVCH; Lázně Bohdaneč ponds (70), 4.vi.2003, 2 f*f*, MT, SW, C, J, M, NMPC; Na Plachtě NM (75), 31.v.1996, 1 f*, SW, Mo, MVCH; Nebeská Rybná (76), 26.vi.2002, 1 f*, SW, H, NMPC; Trčkov NNR (116), 11.vi.2007, 7.vi.2011, 2 f*f*, SW, H, J, S, NMPC; Velká louka meadow NM (123), 19.vi.2002, 1 f*, SW, H, NMPC; Vysoké Chvojno (129), 12. and 20.v.1998, 3 f*f*, SW, Mm, Mo, MVCH.

Comments. A typical subspecies of forest taiga, penetrates from Belgium and Scandinavia to the Ural. The nominate subspecies $H$. $n$. nitidifrons Szil. ranges from Siberia, eastern Russia, Japan to Mongolia and North East China. The southern border of confiformis distribution is limited by Bohemia, Moravia, Slovakia and Ukraine. The first summary map of an occurence in the former Czechoslovakia was introduced by Ježková (1974, p. 74), update map with some additional localities from the Czech Republic by Dvořák (2011b, p. 49). Larvae were found in the littoral zone of forest ponds with swampy banks, as well as in tufts of wet meadows near forest edges. Assessment of the current conservation status in the Czech Republic: NS.

\section{Hybomitra tropica (Linnaeus, 1758)}

Material examined. Běleč nad Orlicí (14), 24.v.1994, 1 f*, SW, Mo, MVCH; Červený Potok (28), 30.v.2003, 1 f*, SW, J, NMPC; Trčkov NNR (116), 7.vi.2011, 5 f*f*, SW, H, J, S, NMPC; Velká louka meadow NM (123), 19.vi.2002, 1 f*, SW, H, NMPC; Vysoké Chvojno (129), 28.v.1998, 1 f*, SW, Mo, MVCH.

Comments. A European species distributed from Spain, countries near North Sea, Scandinavia, Central Europe, Slovenia, Croatia, Serbia to Montenegro. Larvae have been found in the littoral of different forest water reservoirs or flows, swamps and peat bogs. 


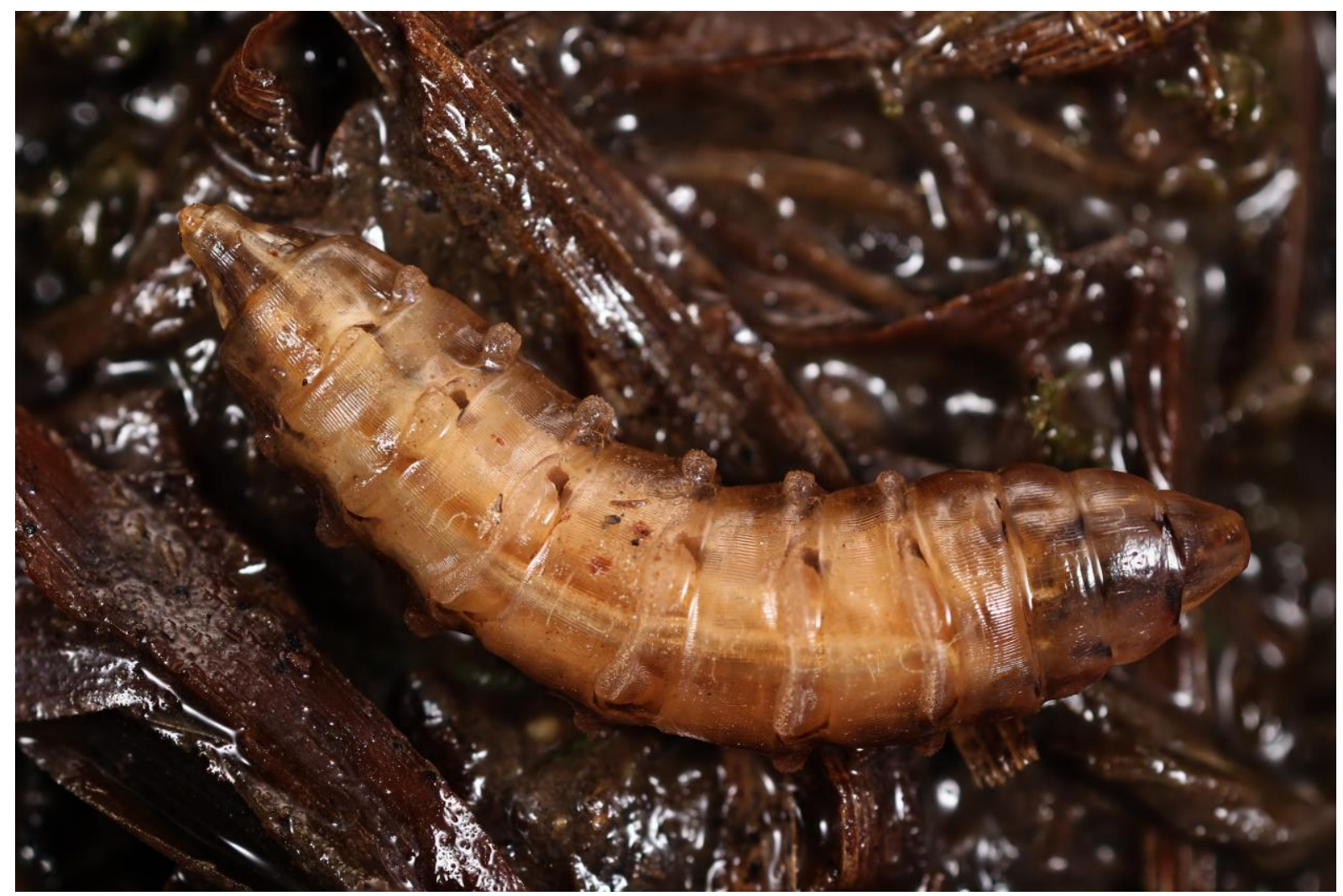

Fig 12: Hybomitra sp. - the last instar larvae collected in swamps of a forest edge meadow.

Photo by Michal Tkoč.

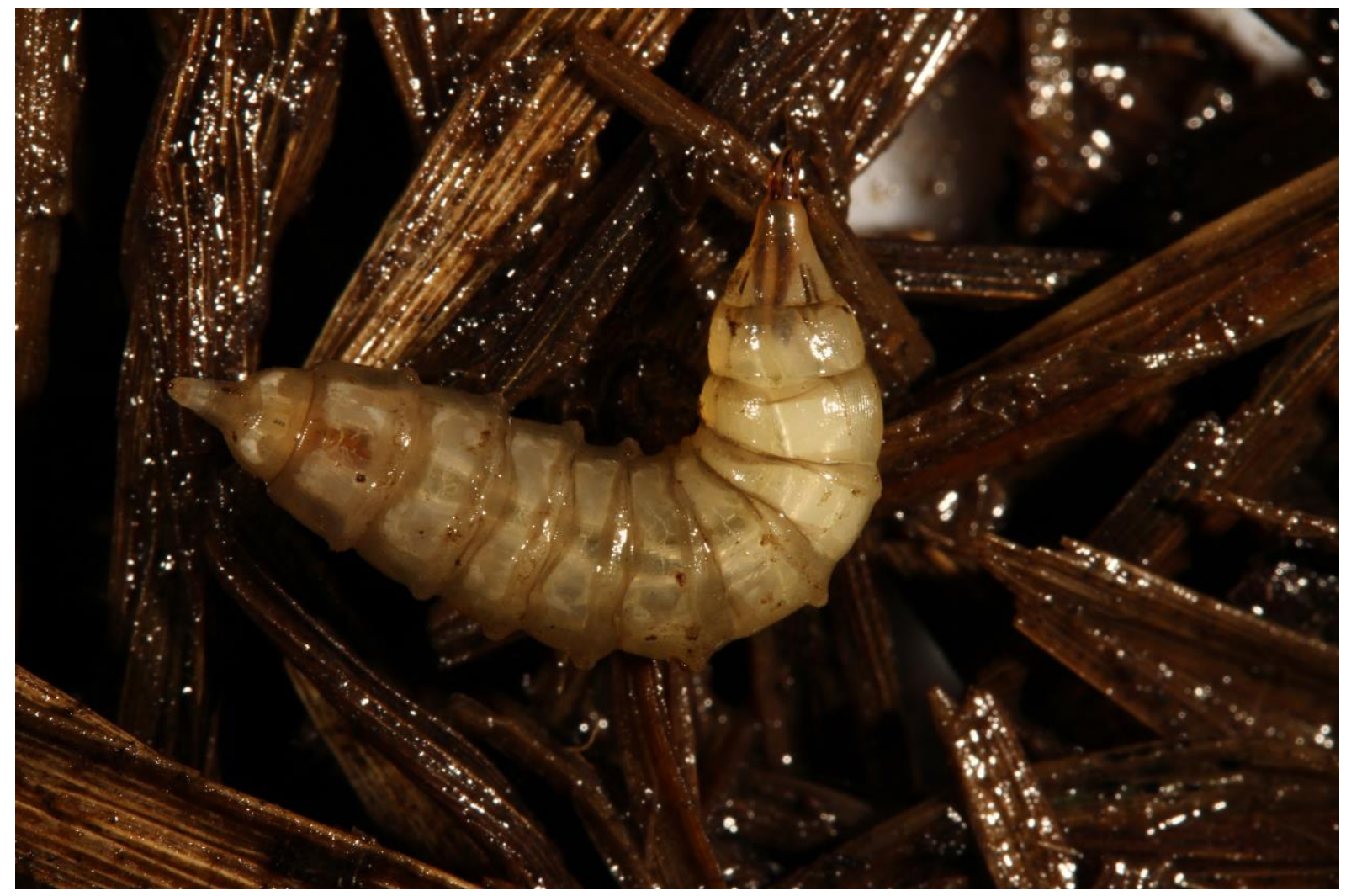

Fig 13: Tabanus maculicornis Zett. - the last instar larvae from a littoral of a forest pond. Photo by Michal Tkoč. 


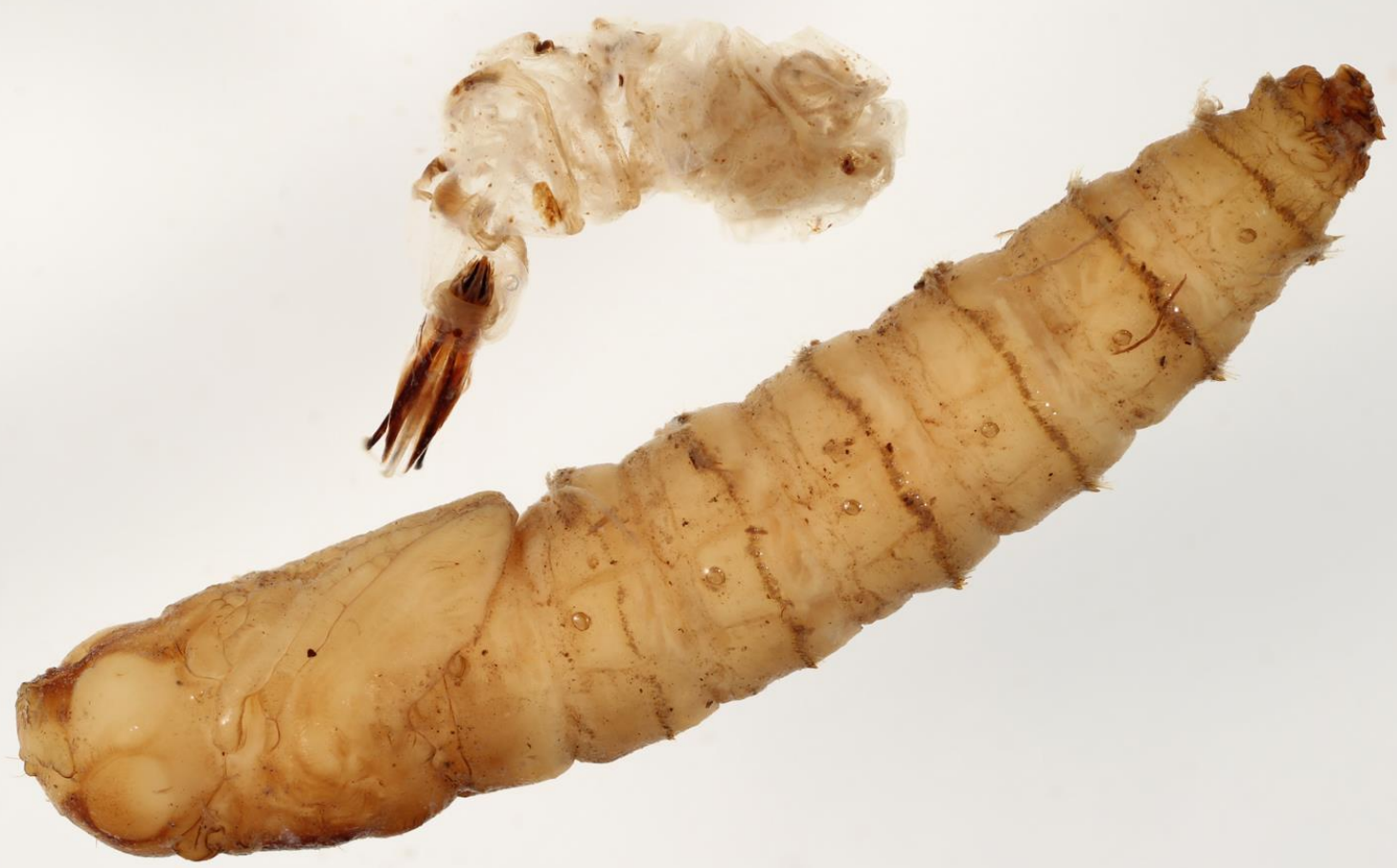

Fig 14: Hybomitra sp. - pupa and exuvia of the last larval instar collected 26.iii.2014 (Adamovo jezero lake env. Petrovice). Photo by Michal Tkoč.

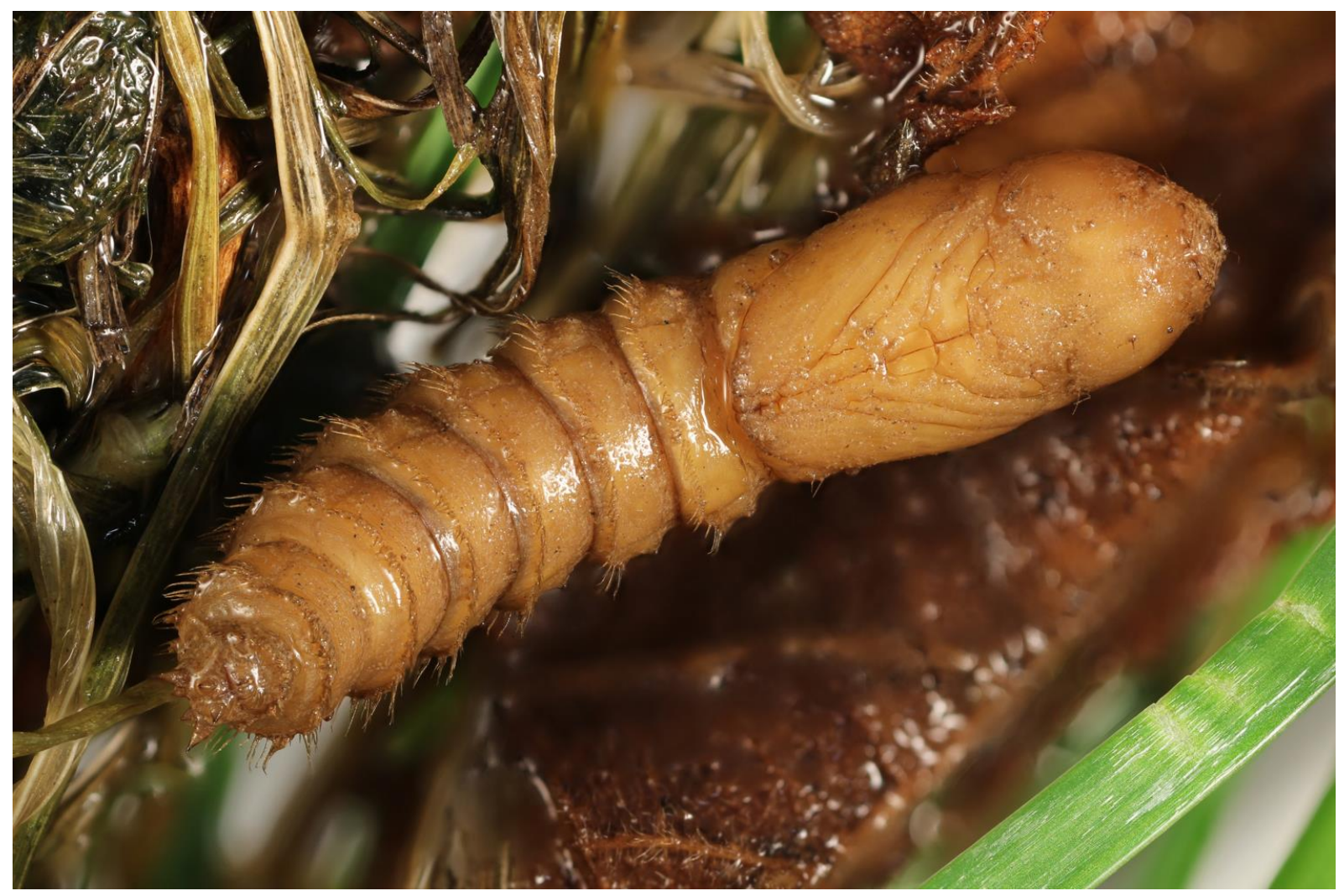

Fig 15: Tabanus bromius L. - pupa collected 26.iii.2014 in waterlogged soil of pastures near Dolní Čermná. Photo by Michal Tkoč. 


\section{Tabanus autumnalis Linnaeus, 1761}

Published records. Vimmer 1913, Moucha \& Chvála 1956a, 1958: Hradec Králové; Formánek 1982: Bohdaneč.

Material examined. Dolní Čermná (33), 9.viii.2004, 1 f*, SW, J, NMPC; Hemže - Mýtkov (39), 19.vii.2004, 2 f***, SW, J, NMPC; Hradec Králové - Pivovarská flošna (51), 25.v.2005, 1 f*, SW, Mo, MVCH; Lázně Bohdaneč - ponds (70), 4. and 24.vi., 16.vii.2003, 23.vi.2004, 4.vii.2005, 10 f*f*, MT, SW, C, J, M, Mo, NMPC; Mělčany - Zlatý potok brook (73), 5.vii. and 24.vii.2002, 6. and 20.viii. and 4.ix.2002, $56 \mathrm{f}^{*} \mathrm{f}^{*}, 1 \mathrm{~m} *$, MT, C, J, M, NMPC; Vamberk (121), vii.1996, 1 f*, SW, JiH, NMPC; Zvonkové údolí valley (135), 25.vi.2003, 1 m*, MT, H, NMPC.

Comments. A Palaearctic species widely distributed almost throughout Europe including the boreal ecoregion Scandinavia, Siberia (absent from northernmost areas), Mediterrannean islands, Caucasus, Middle East, Turkey, Iran, Iraq, Afghanistan, Central Asia, China, Mongolia and North Africa. Also collected, rarely, at higher altitudes (ridges of mountains). Larvae have been found in the muddy littoral of ponds, lakes and large artificial water reservoirs; the life cycle may take up to two years.

\section{Tabanus bovinus Linnaeus, 1758}

Published records. Landrock 1932: Jeseníky; Moucha \& Chvála 1961: Nové Město nad Metují; Ježková 1974: Hradec Králové, Peklo, Praděd; Formánek 1982: Bohdaneč.

Material examined. Bohuslavice nad Metují (16), 12.vi.1963, 1 m*, SW, Su, MVCH; Zdobnice (130), 24.vii.1962, 1 f*, SW, Ce, MVCH.

Comments. Known throughout Europe, in Asia across Turkey, Siberia to Altai, some republics of Central Asia (former U.S.S.R.) and North Africa. Larvae inhabit banks of rivers, river channels, ponds and lakes.

\section{Tabanus bromius Linnaeus, 1758}

Published records. Landrock 1907, Moucha \& Chvála 1956c: Svitavy; Czižek 1908, Moucha \& Chvála 1956c, 1958: Jeseníky; Vimmer 1913, Moucha \& Chvála 1956a: Vamberk, Žamberk; Moucha \& Chvála 1956a: Česká Skalice, Česká Třebová, Police nad Metují; Moucha \& Chvála 1956c: Praděd; Moucha \& Chvála 1961: Nové Město nad Metují, Malá Morávka; Ježková 1974: Červený Kostelec, Horní Čermná, Horní Lipka, Hradec Králové, Karlova Studánka, Náchod, Nepomuky, Potštejn, Suchý vrch env. Jablonné nad Orlicí, Týniště nad Orlicí, Velký Vřeštov, Javorník, Jeseník, Karlova Studánka, Velké Losiny; Formánek 1982: Bohdaneč.

Material examined. Adamovo jezero lake (1), 6.vii.2011, 7.vii.2012, 93 f*f*, SW, J, NMPC; Amerika (2), 4.ix.1997, $3 \mathrm{f}^{*} \mathrm{f}^{*}$, SW, H, NMPC; Antoniino údolí valley (4), 17.vi.2003, 11.vi.2007, $78 \mathrm{f}^{*} \mathrm{f}^{*}, \mathrm{SW}, \mathrm{H}, \mathrm{NMPC}$; Bedřichovka (6), vii.2007, 2 f***, MT, H, NMPC; Benátky (7), 27.viii.1996, 3 f*f*, SW, JiH, NMPC; Čenkovička brook NM (23), 25.vii.2006, 1 f*, SW, J, NMPC; Česká Třebová (29), vii., 1 f*, SW, V, NMPC; Dolní Čermná (33), 31.vii.1978, vii.1982, 8 f***, SW, J, NMPC; Horní Čermná (43), 28.vii.-7.viii.1964, 13 f*f*, SW, J, NMPC; Horní Morava - Zátiší (45), 14.vii.2001, 1 f*, SW, J, NMPC; Horní Redice - Mordýř pond (46), 21.vii.2003, 2 f***, SW, J, NMPC; Kamenný kopec hill (60), 18.vii.1998, 2 f*f*, SW, J, NMPC; Karlova Studánka (62), 4.vii.1968, 1 f*, SW, J, NMPC; Klečkov - Poříčí (63), 27.vi.1994, 38 f*f*, SW, J, NMPC; Lázně

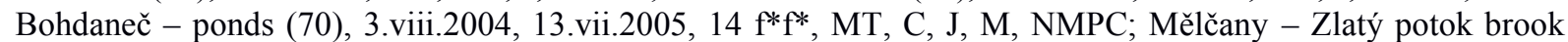
(73), 18.vi., 5. and 24.vii., 6. and 20.viii.2002, $123 \mathrm{f}^{*} \mathrm{f}^{*}$, MT, C, J, M, NMPC; Nebeská Rybná (76), 26.vi.2002, 2 f*f*, SW, H, NMPC; Nepomuky (77), 6.viii.1964, 1 f*, SW, J, NMPC; Neratov (78), 10.vi.1998, 1 f*, SW, H, NMPC; Orlické Záhoří (82), 29.vi.1994, 1 f*, SW, J, NMPC; Plchůvky (88), 22.vii.1962, 1 f*, SW, D, MVCH; Podlesí (89), 12.vi.2007, 1 f*, SW, H, NMPC; Pod Sfingou NM (90), 25.vi., 22.vii.2003, 4 f*f*, MT, H, NMPC; Pod Zakletým NR (91), 16.viii.1995, 1 f*, YPT, H, NMPC; Rašeliniště Kačerov NR peatbog (98), 28.vi.1994, 11.vii. and 1.viii.2008, $3 \mathrm{f}^{*} \mathrm{f}^{*}, \mathrm{MT}, \mathrm{SW}, \mathrm{H}, \mathrm{J}$, NMPC; Ruprechtice (102), 20.vii.1998, $1 \mathrm{f} *$, SW, J, NMPC; Sopotnice - Pod horou (109), 1.-15.viii.1996, 15.and 25.viii.1997, 6 f*f*, 1 m*, MB, H, NMPC; Trčkov NNR (116), 20.vi.1997, 17.vi.2003, $11 \mathrm{f}^{*} \mathrm{f}^{*}$, SW, H, NMPC; Vrchní Orlice (126), 15.vii.2010, 10 f*f*, MT, H, NMPC; Vysoké Chvojno (129), 17.vi.1998, 1 m*, SW, Mo, MVCH; Zelenka (131), 11. and 14.viii.2009, $2 \mathrm{f}^{*} \mathrm{f}^{*}, \mathrm{MT}, \mathrm{H}$, NMPC; Zemská brána (133), 19.vi.2003, 6 f***, SW, H, NMPC; Zvonkové údolí valley (135), 21.vii.2003, 1 f*, 1 m*, MT, H, NMPC; Žamberk (136), vii., 1 f*, SW, V, NMPC.

Immature stages. Olešnice v Orlických horách (81), 1 f* ex larva collected 4.v.1999, H, J; eclosion v.1999; exuvia of larva in the eth./coll. NMPC n. 209. Same (81), 2 m*m* ex larvae collected 4.v.1999, H, J; eclosion v.1999, exuviae of larvae and partly pupae in the eth./coll. NMPC n. 208, 210 - with a pinned exuvia of pupa. 
Velká louka meadow NM (123), $1 \mathrm{f*}$ ex larva collected 6.v.1999, H, J; eclosion v.1999, exuvia of larva in the eth./coll. NMPC n. 211, exuvia of pupa pinned.

Comments. A widely distributed European-West-Siberian forest and steppe species, collected at various altitudes; Central Asia and North Africa. It is supposed to transmit tularemia, anthrax and trypanosomyiasis. Larvae have been found in a littoral of water reservoirs, banks of brooks and small rivers, but also far from water in meadows and pasturelands.

\section{Tabanus cordiger Meigen, 1820}

Published records. Moucha \& Chvála 1956c: Silesia; Formánek 1982: Bohdaneč.

Material examined. Adamovo jezero lake (1), 6.vii.2011, 2 f***, SW, J, NMPC; Nová Ves env. Orlické Záhoří (80), 20.vii.2004, 1 f*, MT, H, NMPC; Rašeliniště Kačerov NR peatbog (98), 10.vi.1997, 1 f*, SW, H, NMPC; Velká louka meadow NM (123), 14.vi.2014, 1 f*, SW, Mm, NMPC.

Comments. Widely distributed throughout Europe from the British Islands and Scandinavia as far as the southern Ural; southern limit extends from the Canary Islands, North Africa, Near East, Caucasus to Iran. Reophilous larvae can be found among emergent herbaceous vegetation of small rivers and below stones on the bottom of streams, mostly preferring places with sandy banks. The life cycle takes up to two years.

\section{Tabanus glaucopis Meigen, 1820}

Published records. Moucha \& Chvála 1961: Červenohorské sedlo, Nové Město nad Metují; Ježková 1974: Horní Čermná.

Material examined. Adamovo jezero lake (1), 6.vii.2011, $2 \mathrm{f}^{*} \mathrm{f}^{*}$, SW, J, NMPC; Benátky (7), 27.viii.1996, $1 \mathrm{f}^{*}$, SW, JiH, NMPC; between Šanov and Jeřáb Mt. (13), 28.vii.2006, 2 f***, SW, J, NMPC; Bukačka NNR (20), 18.vii.-5.viii.1994, 1 f*, MT, H, Va, NMPC; Peklo - Jestřebí (85), 29.vii.2002, 1 f*, SW, J, NMPC; Prameny near Žárová (92), 26.vii.1995, 1 f*, SW, J, NMPC; Rašeliniště Pod Předním vrchem peatbog (99), 18.vii.8.viii.1994, 1 f*, YPT, H, Va, NMPC; Sopotnice - Pod horou (109), 25.viii.1997, 1 f*, MB, H, NMPC; Zlatý Potok (134), 14.viii.2001, 1 f*, SW, J, NMPC.

Comments. A species of Eurosiberian distribution, widespread throughout Europe as far as the Caucasus, Turkey, Iran, Mongolia, China and the Far East. Biology of immature stages is insufficiently known, only a single larva from a river bank has been reared to eclosion (Andrejeva 1990).

\section{Tabanus maculicornis Zetterstedt, 1842}

Published records. Moucha \& Chvála 1961: Nové Město nad Metují; Ježková 1974: Horní Lipka, Hradec Králové, Karlov, Karlova Studánka, Náchod, Police nad Metují, Praděd, Rejvíz, Suchý vrch env. Jablonné nad Orlicí, Vrbno pod Pradědem; Formánek 1982: Bohdaneč.

Material examined. Adamovo jezero lake (1), 6.vii.2011, 7.vii.2012, $7 \mathrm{f}^{*} \mathrm{f}^{*}$, SW, J, NMPC; Anenský vrch Mt. (3), 11. and 23.vii.2008, 4 f***, MT, H, NMPC; Antoniino údolí valley (4), 17.vi.2003, 11.vi.2007, 8 f*f*, SW, H, NMPC; Bedřichovka (6), 23.vii.2003, 20.vii.2004, vii.2007, 59 f***, MT, H, NMPC; Bukačka NNR (20), 1. and 22.vii.2009, 7.vi.2011, 9 f***, 2 m*m*, MT, SW, H, J, NMPC; Buková hora Mt. (21), 12.vii.2006, 1 f*, SW, J, NMPC; Černý důl valley (25), 25.vi.2003, 1 m*, PT, H, NMPC; České Meziříčí - Zbytka NR (30), 5.18.vi.1996, 1 f*, MT, Mo, MVCH; Deštné v Orlických horách (32), 11.vi.1997, 1 f*, SW, H, NMPC; Dolní Čermná (33), 31.vii.1978, 12 f***, SW, J, NMPC; Dolní Morava (36), 19.vii.2006, 1 f*, SW, J, NMPC; Dolní Radechová (37), 5.vi.1971, 1 f*, SW, Ms, MVCH; Horní Morava - Zátiší (45), 14.vii.2001, 30.v.2003, 2 f*f*, SW, J, NMPC; Hořečky NR (47), 9.vi.2009, 5 f*f*, SW, H, NMPC; Jablonné nad Orlicí (54), 11.vii.1981, 1 f*, SW, J, NMPC; Jadrná (55), 3.vii.1998, 16 f*f*, SW, H, NMPC; Klečkov - Poříčí (63), 27.vi.1994, 15 f*f*, SW, J, NMPC; Mělčany - Zlatý potok brook (73), 5.vii.2002, 1 f*, MT, C, J, M, NMPC; Nebeská Rybná (76), 26.vi.2002, 3 f*f*, SW, H, NMPC; Nepomuky (77), 12.vii.1981, 3 f*f*, SW, J, NMPC; Neratov (78), 10.vi.1998, 5 f***, SW, H, NMPC; Nová Ves env. Orlické Záhoří (80), 18.vii.2006, 2 f*f*, MT, H, NMPC; Olešnice v Orlických horách (81), 22.vi.1995, 1 m*, SW, J, NMPC; Orlické Záhoří (82), 29.vi.1994, 4 f***, SW, J, NMPC; Ošerov (84), 12.vii.2006, 24. and 26.vi., 9.vii.2008, 8.vi.2011, $26 \mathrm{f}^{*} \mathrm{f}^{*}, 3 \mathrm{~m} * \mathrm{~m}^{*}$, SW, ET, MT, H, J, NMPC; Pěticestí crossway (87), 11.vi.1996, $1 \mathrm{f}^{*} \mathrm{f}^{*}$, SW, JiH, NMPC; Podlesí (89), 12.vi.2007, 8 f*f*, SW, H, NMPC; Pod Sfingou NM (90), 22.vii.2003, 3 f***, 1 m*, MT, H, NMPC; Prudký potok brook - Mokřiny (95), 4.vii.2005, 1 f*, MT, H, J, NMPC; Rašeliniště Kačerov NR peatbog (98), 28.vi.1994, 10.vi.1998, 3.vii.2007, 
11.vii., 1.viii.2008, 12 f*f*, $1 \mathrm{~m} *$, MT, SW, H, J, NMPC; Selské vrchy hills - Mlýnský potok brook (105),

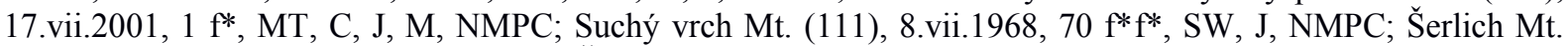
(112), 8.vi.2011, 7 f*f*, SW, J, NMPC; Špičák quarry near Plasnice (114), 8.vi.2011, 32 f*f*, SW, J, NMPC; Trčkov NNR (116), 16.-30.vi, 29.vi.-18.vii.1994, 17.-25.vi.2003, 12.vii.2005, 11.vi.2007, 7.vi.2011, 97 f*f*, 3 m*m*, MT, SW, MB, H, J, S, Va, NMPC; Trčkovská louka meadow (117), 17.-23.v.1995, 18.viii.2004, 3 f*f*, SW, MT, H, M, NMPC; Velká louka meadow NM (123), 19.vi.2002, 9.vii., 22.viii.2008, 3 f*f*, 1 m*, MT, SW, H, NMPC; Vrchní Orlice (126), 15.vii.2010, 1 f*, 3 m*m*, SW, J, NMPC; Vysoké Chvojno (129), 26.v.1994 and 28.vi.1995, 2 f*f*, SW, Mo, MVCH; Zelenka (131), 1. and 22.vii.2009, 8 f*f*, $4 \mathrm{m*m*}$, MT, H, NMPC; Zemská brána (133), 19.vi.2003, 22 f*f*, SW, H, NMPC; Zvonkové údolí valley (135), 18.vi.1999, 25.vi., 21.vii.2003, $7 \mathrm{f} * \mathrm{f} *, 9 \mathrm{~m} * \mathrm{~m} *$, MT, H, NMPC.

Immature stages. Trčkov NNR (116), 1 m* ex larva collected 19.-22.iv.1999, H, J; eclosion v.1999, exuviae of larva and pupa in the eth./coll. NMPC n. 11. Velká louka meadow NM (123), $5 \mathrm{f}^{*} \mathrm{f}^{*}$ ex larva collected 6.v.1999, H, J; eclosion v.1999, exuviae of larvae and pupae in the eth./coll. NMPC n. 40, 45, 54, 159, 181. Same (123), $20 \mathrm{~m} * \mathrm{~m} *$ ex larva collected 6.v.1999, H, J; eclosion v.1999, exuviae of larvae and pupae in the eth./coll. NMPC n. $33,37-39,41,46-48,55-58,152,154,157-158,161,166,168,192$. Vrchní Orlice (126), 1 m* ex larva collected 5.v.1999, H, J; eclosion v.1999, exuvia of larva and pupa in the eth./coll. NMPC n. 191.

Comments. A European-West-Siberian species: known throughout Europe including boreal ecoregion Scandinavia and western Siberia; also Caucasus, Kazakhstan and Baikal. Habitats of larvae are the same as in T. bromius.

\section{Tabanus quatuornotatus Meigen, 1820}

Published records. Landrock 1932: Jeseníky; Moucha \& Chvála 1958: Hradec Králové; Moucha \& Chvála 1961: Nové Město nad Metují.

Comments. A forest - steppe species of South and Central Europe ranging from Spain to the Balkan Peninsula, Turkey, Transcaucasia and Iran. North Africa: Morocco, Tunisia. The northern limit of its distribution in Europe runs through Belgium, Germany, Poland and Ukraine. Larvae are edaphic, inhabiting turfs of dry meadows and pastures.

\section{Tabanus spodopterus Meigen, 1820}

Published record. Ježková 1974: Javorník.

Comments. Restricted to hilly and montane pastures of Central and Southern Europe (including southern parts of Russia). Biology unknown.

\section{Tabanus sudeticus Zeller, 1842}

Published records. Czižek 1908, Moucha \& Chvála 1956a, 1958: Jeseníky; Vimmer 1913, Moucha \& Chvála 1956a, 1958a: Hradec Králové; Moucha \& Chvála 1956c: Silesia; Moucha \& Chvála 1958: Králický Sněžník, Žulová; Ježková 1974: Javorník, Petrovy Kameny, Šumná near Šumperk, Velké Losiny.

Material examined. Bělečko (15), 4.viii.1973, 1 f*, SW, Pr, MVCH; Dolní Čermná (33), vii.1982, 1 f*, SW, J, NMPC; Vysoké Chvojno (129), 9.-31.vii.1998, 1 f*, MT, Mo, MVCH.

Comments. A European-West-Siberian species, rare in lowlands, a typical boophilous insect in areas of hills and mountains. Habitats of larvae include swamps near forest water reservoirs. The species may require three years to complete its life cycle (Andreeva 1990).

\section{Haematopota crassicornis Wahlberg, 1848}

Published records. Czižek 1907, Landrock 1932, Moucha \& Chvála 1956c: Šumperk; Ježková 1974: Horní Lipka.

Material examined. Anenský vrch Mt. (3), 26.vi., 11. and 23.vii.2008, 7 f* $\mathrm{f}^{*}$, MT, H, NMPC; Bedřichovka (6), 25.vi.2003, 2 f*, MT, H, NMPC; Bukačka NNR (20), 17.vi.1996, 1 f*, SW, JiH, NMPC; Dolní Čermná (33), vii.1982, 8 f*f*, SW, J, NMPC; Dolní Morava (36), 2.vi.1999, 1 f*, SW, J, NMPC; Horní Lipka (44), 12.vi.1972, $3 \mathrm{f}^{*} \mathrm{f}^{*}$, SW, J, NMPC; Jadrná (55), 3.vii.1998, 1 f*, SW, H, NMPC; Lázně Bohdaneč - ponds (70), 4. and 24.vi.2003, 9.vi.2005, 5 f*f*, 1 m*, MT, C, J, M, Mo, NMPC; Ošerov (84), 24.vi.2008, 3 f*f*, 1 m*, ET, H, NMPC; Rašeliniště Kačerov NR peatbog (98), 3.vii.2007 and 11.vii.2008, $2 \mathrm{f}^{*} \mathrm{f}^{*}, 1 \mathrm{~m} *$, MT, H, NMPC; Sedloňov - Polom (104), 20.viii.2005, 1 m*, MT, H, NMPC; Trčkov NNR (116), vi.1997, 28.vii.2003 and 
7.vi.2011, 2 f*f*, 1 m*, MB, SW, MT, H, JiH, P, NMPC; Velká louka meadow NM (123), 24.vi.2008, 1 f*, MT, H, NMPC; Vysoká nad Labem (127), 23.v.1986, 1 f*, SW, Mo, MVCH; Zelenka (131), 11.viii.2009, 1 f*, MT, $\mathrm{H}, \mathrm{NMPC}$.

Comments. A European-West-Siberian forest species known from Spain to the British Isles, Scandinavia, Ural and western Siberia. Larvae have been found on muddy shorelines of ponds and lakes, swampy forests and small meander rivers (Ježek 1971).

\section{Haematopota italica Meigen, 1804}

Published records. Vimmer 1913, Moucha \& Chvála 1956a, b, 1967: Hradec Králové; Moucha \& Chvála 1956b, 1967: Žulová; Moucha \& Chvála 1961, 1967: Nové Město nad Metují; Moucha \& Chvála 1967: Týniště nad Orlicí, Skrbovice; Ježková 1974: Nepomuky, Police nad Metují.

Material examined. Nepomuky (77), 6.viii.1964, 2 f***, SW, J, NMPC; Osíkov (83), 15.vii.1998, 1 f*, SW, J, NMPC.

Comments. A European species distributed from the Iberian Peninsula, North Sea coast and Sweden to the Ural, Caspian Sea and Turkey. Larvae were described by Folco (1934). Habitats of immature stages are probably the same as quoted for the other Haematopota species listed here.

\section{Haematopota pluvialis (Linnaeus, 1758)}

Published records. Moucha \& Chvála 1956c: Praděd Mt., valley of the Desná river, Sobotín; Moucha \& Chvála 1961: Nové Město nad Metují; Ježková 1974: Červený Kostelec, Dolní Lipová, Horní Čermná, Horní Lipka, Hradec Králové, Karlov, Náchod, Nepomuky, Police nad Metují, Suchý vrch env. Jablonné nad Orlicí, Týniště nad Orlicí, Věkoše, Černá Voda, Dolní Lipová, Jeseník, Karlov, Karlova Studánka, Nová Ves, Rejvíz, Vrbno, Žulová; Formánek 1982: Bohdaneč.

Material examined. Adamovo jezero lake (1), 6.vii.2011, 7.vii.2012, 77 f*f*, SW, J, NMPC; Anenský vrch Mt. (3), 11. and 23.vii.2008, $1 \mathrm{f}^{*}, 4 \mathrm{m*} \mathrm{m}^{*}, \mathrm{MT}, \mathrm{H}, \mathrm{NMPC}$; Antoniino údolí valley (4), 11.vi.2007, $1 \mathrm{f*}, \mathrm{SW}, \mathrm{H}$, NMPC; Bartošovice v Orlických horách (5), 20.-29.vi.1994, 1 f*, YPT, H, P, Va, NMPC; Bedřichovka (6), 8.viii.2002, 25.vi., 23.vii. and 19.viii.2003, 20.vii. and 18.viii.2004, $20 \mathrm{f}^{*} \mathrm{f}^{*}, 20 \mathrm{~m} * \mathrm{~m}^{*}$, MT, H, NMPC; Bernartice - Vrchová (8), 2.viii.1994, 1 f*, SW, Mo, MVCH; between Hynčice pod Sušinou and Chrastice (9), 31.vii.2001, 2 f*f*, SW, J, NMPC; between Pasínky and Bystřina (11), 31.vii.2001, 5 f*f*, SW, J, NMPC; between Podlesí and Vysoký Potok (12), 26.vii.2001, 9 f***, SW, J, NMPC; between Šanov and Jeřáb Mt. (13), 28.vii.2006, 1 f*, SW, J, NMPC; Běleč nad Orlicí (14), 1.vii.1986, 2 f*f*, SW, Mo, MVCH; Broumarské slatiny swamps NM (18), 24.vii.1962, 1 f*, SW, Ce, MVCH; Bukačka NNR (20), 28.vi.-18.vii.1994, 22.vii.2009, 2 f*f*, MT, H, Va, NMPC; Buková hora Mt. (21), 12.vii.2006, 3 f***, SW, J, NMPC; Čenkovička brook NM (23), 25.vii.2006, $4 \mathrm{f}^{*} \mathrm{f}^{*}$, SW, J, NMPC; Černý potok brook (26), 23.vi.2005, 1 f*, MT, H, NMPC; Červená Voda (27), 16.vii.2006, 1 f*, SW, J, NMPC; České Meziříčí - Zbytka NR (30), 18.-28.vi., 15.-22.vii., 31.vii.-21.viii., 21.viii.-4.ix.1996, 15.-22.vii.2002, 14 f*f*, 1 m*, SW, MT, YPT, J, Mo, NMPC, MVCH; Dolní Čermná (33), 4.vii. and 13.vii.1975, 31.vii.1978, 10.vii.1981, vii.1982, $153 \mathrm{f}^{*} \mathrm{f}^{*}, 3 \mathrm{~m}^{*} \mathrm{~m}^{*}$, SW, J, NMPC; Dolní Hedeč (34), 20.viii.2001, 1 f*, SW, J, NMPC; Dolní Lipová (35), 7.vii.1968, 2 f***, SW, J, NMPC; Dolní Morava (36), 19.vii.2006, 5 f*f*, SW, H, NMPC; Dolní Radechová (37), 7.vii.1971, 1 f*, SW, Ms, MVCH; Dubno NR (38), 12.vii.1999, 2 f*f*, SW, Mo, MVCH; Hemže - Mýtkov (39), 19.vii.2004, 2 f*f*, SW, J, NMPC; Heroltice (40), 23.vii.1997, 1 f*, SW, J, NMPC; Hoděšovice (42), 5. and 24.viii.1987, $3 \mathrm{f}^{*} \mathrm{f}^{*}, 1 \mathrm{~m}^{*}$, SW, Mo, MVCH; Horní Čermná (43), 28.vii.-7.viii.1964, 4 f*f*, SW, J, NMPC; Horní Morava - Zátiší (45), 14.vii.2001, 3 f*f*, SW, J, NMPC; Horní Ředice - Mordýř pond (46), 21.vii.2003, 3 f*f*, SW, J, NMPC; Hořečky NR (47), 11.viii.2009, 2 f*f*, 1 m*, MT, H, NMPC; Hradec Králové - Malšovice (48), 29.vii.1996, 1 m*, SW, Mo, MVCH; Hradec Králové - Nový Hradec Králové (49), 10.vii.1959, 1f*, SW, Ce, Ru, MVCH; Hradec Králové - Piletice (50), 18.vi.2014, 1 m*, SW, Mo, MVCH; Hronov (52), 4.viii.1998, 26.vii.1999, 2 f*f*, SW, J, NMPC; Jablonné nad Orlicí (54), 11.vii.1981, 14 f*f*, SW, J, NMPC; Jadrná (55), 3.vii.1998, 7 f*f*, SW, H, NMPC; Jetřichov (57), 14.vii. and 4.viii. 1999, $4 \mathrm{f}^{*} \mathrm{f}^{*}, \mathrm{SW}$, Mo, MVCH; Jiskrovo údolí valley (58), 19.vii.2004, 2 f*f*, SW, J, NMPC; Julinčino Údolí (59), 15.vii.1984, 1 f*, SW, Mo, MVCH; Kamenný kopec hill (60), 18.vii.1998, 2 f*f*, SW, J, NMPC; Karlov pod Pradědem (61), 5. and 6.vii.1968, 3 f*f*, SW, J, NMPC; Karlova Studánka (62), 4.vii.1968, 1 f*, SW, J, NMPC; Klečkov - Poříčí (63), 27.vi.1994, 3 f***, SW, J, NMPC; Kouty nad Desnou (65), 6.vii.1957, 1 f*, SW, Zu, ZPC; Králíky - Vyhlídka hill (68), 10.vii.2001, 1 f*, SW, J, NMPC; Kunčice (69), 28.vii.2001, $2 \mathrm{f}^{*} \mathrm{f}^{*}$, SW, J, NMPC; Lázně Bohdaneč - ponds (70), 18.vii.1995, 7.viii.2001, 4. and 24.vi., 16.vii., 7.viii., 6.ix.2003, 23. and 28.vi., 7. and 16.vii., 3., 18. and 25.viii., 15.ix.2004, 9.vi., 4., 13. and 21 .vii., 13.viii., 2. and 25.ix.2005, $1864 \mathrm{f}^{*} \mathrm{f}^{*}, 47 \mathrm{~m} * \mathrm{~m} *$, SW, MT, C, F, J, M, Mo, V, NMPC, MVCH; Libišany (71), 19.vi.1996, 1 
m*, SW, Mo, MVCH; Lohenice (72), 29.vi.2000, 1 m*, SW, Mo, MVCH; Mělčany - Zlatý potok brook (73), 5. and 24.vii., 6. and 20.viii., 4.ix.2002, $56 \mathrm{f}^{*} \mathrm{f}^{*}, 1 \mathrm{~m}^{*}$, MT, C, J, M, NMPC; Na Plachtě NM (75), 2.ix.1983, 1 f*, SW, Mo, MVCH; Nebeská Rybná (76), 26.vi.2002, 1 f*, SW, H, NMPC; Nepomuky (77), 6.viii.1964, 12.vii.1981, 22.vii.1982, 70 f*f*, SW, J, NMPC; Neratov (78), 10.vi.1998, 1 m*, SW, H, NMPC; Nová Ves env. Borohrádek (79), 27.viii.1997, 1 f*, SW, Mo, MVCH; Nová Ves env. Orlické Záhoří (80), 20.vii.2004, 18.vii. and 7.ix.2006, $14 \mathrm{f}^{*} \mathrm{f}^{*}, \mathrm{MT}, \mathrm{PT}, \mathrm{H}, \mathrm{NMPC}$; Olešnice v Orlických horách (81), 14.viii.1993, 22. and 26.vi.1996, 3 f*f*, 2 m*m*, SW, J, JiH, NMPC; Orlické Záhoří (82), 29.vi.1994, 1 f*, SW, J, NMPC; Ošerov (84), 3.viii.2006, 24. and 26.vi., 9. and 24.vii., 22.viii.2008, $11 \mathrm{f}^{*} \mathrm{f}^{*}, 2 \mathrm{~m}^{*} \mathrm{~m}^{*}$, ET, MT, H, NMPC; Peklo nad Zdobnicí (86), 1.viii.1996, 3 f*f*, SW, J, NMPC; Plchůvky (88), 22.vii.1962, 1 f*, SW, D, MVCH; Podlesí (89), 26.vi.1996, 1 f*, SW, JiH, NMPC; Pod Sfingou NM (90), 9.viii.1993, 11.vii.2002, 22.vii.2003, 6 f*f*, 1 m*, MT, SW, H, J, NMPC; Prameny near Žárová (92), 26.vii.1995, 7 f*f*, SW, J, NMPC; Prochody (93), 4.viii.1997, 1 f*, SW, J, NMPC; Prostřední Lipka (94), 14.vii.2001, 1 f*, SW, J, NMPC; Přelouč - Slavíkovy ostrovy (96), 23.vii.2000, 1 f*, SW, Mo, MVCH; Račice nad Trotinou (97), 20.vii.1993, 1 f*, SW, Mo, MVCH; Rašeliniště Kačerov NR peatbog (98), 28.vi., 18.vii.-8.viii.1994, 3. and 24.vii.2007, 11.vii. and 1.viii.2008, $9 \mathrm{f} * \mathrm{f} *, 5 \mathrm{~m} * \mathrm{~m} *$, MT, SW, YPT, H, J, Va, NMPC; Rašeliniště Pod Předním vrchem peatbog (99), 18.vii.-8.viii.1994, 1 m*, YPT, H, Va, NMPC; Rokytnice v Orlických horách (100), 1.viii.1993, 10.viii.1995, 3 f***, SW, J, NMPC; Sedloňov - Polom (104), 12.vii.2005, 1 f*, MT, H, NMPC; Selské vrchy hills - Mlýnský potok brook (105), 29.vi., 2.viii.2001, 3.viii.2006, 5 f*f*, MT, SW, C, J, M, Ve, NMPC; Sklené (107), 23.vii.2001, 1 f*, SW, J, NMPC; Skuhrov nad Bělou (108), 6.viii.1995, 1 f*, SW, J, NMPC; Sopotnice - Pod horou (109), 28.vi. and 1.-15.viii.1996, 15. and 25.viii.1997, 17 f*f*, SW, MB, H, JiH, NMPC; Suchý vrch Mt. (111), 8.vii.1968, 11.vii.1981, 20 f*f*, SW, J, NMPC; Štíty - Na Kluči (115), 23.vii.2004, 2 f*f*, SW, J, NMPC; Trčkov NNR (116), 18.vii.-5.viii.1994, 3 f*f*, 3 m*m*, MT, YPT, H, Va, NMPC; Trčkovská louka meadow (117), 20. and 29.viii.1996, vi.1997, 20.vii., 18.viii.2004, 9 f*f* 2 m*m*, MT, H, NMPC; Velká louka meadow NM (123), 9. and 24.vii.2008, 5 f*f*, MT, H, NMPC; Vrbno pod Pradědem (125), 30.vi.1960, 3.vii.1968, 2 f***, 1 m*, SW, J, Zu, NMPC, ZPC; Vysoká Srbská (128), 31.vii.1999, 1 f*, SW, J, NMPC; Zelenka (131), 22.vii., 11. and 14.viii., 3.ix.2009, 308 f*f*, 16 m*m*, MT, H, NMPC; Zemská brána (133), 5.viii.1994, 19.vi.2003, 7 f***, SW, H, J, NMPC.

Comments. A widely distributed species known throughout Europe eastwards to eastern Siberia, Tien-shan, Turkey and China. Supposed to be a vector of tularemia and anthrax. Larvae have been found far from water in meadows, pastures and dumps of open-cast coal mines.

\section{Haematopota scutellata (Olsufjev, Moucha \& Chvála, 1964)}

Material examined. Adamovo jezero lake (1), 7.vii.2012, 1 f*, SW, J, NMPC; Anenský vrch Mt. (3), 11. and 23.vii., 22.viii.2008, $3 \mathrm{f}^{*} \mathrm{f}^{*}$, MT, H, NMPC; Bedřichovka (6), 23.vii., 19.viii.2003, $4 \mathrm{f}^{*} \mathrm{f}^{*}$, MT, H, NMPC; Dolní Čermná (33), vii.1982, 1 f*, SW, J, NMPC; Dolní Morava (36), 19.vii.2006, 1 f*, SW, J, NMPC; Jablonné nad Orlicí (54), 11.vii.1981, 1 f*, SW, J, NMPC; Moravský Karlov (74), 17.viii.2006, 1 f*, SW, J, NMPC; Nepomuky (77), 12.vii.1983, 1 f*, SW, J, NMPC; Olešnice v Orlických horách (81), 14.viii.1993, 1f*, SW, J, NMPC; Ošerov (84), 3.viii.2006, 22.viii.2008, 3 f**, ET, MT, H, NMPC; Pod Sfingou NM (90), 11.vii.2002, 19.viii.2003, $4 \mathrm{f}^{*} \mathrm{f}^{*}, 2 \mathrm{~m} * \mathrm{~m}^{*}$, MT, H, NMPC; Pod Zakletým NR (91), 31.vii.1995, $1 \mathrm{f} *$, YPT, H, NMPC; Rašeliniště Kačerov NR peatbog (98), 20.-28.vi. and 18.vii.-8.viii.1994, 24.vii.2007, 11.vii., 11.viii.2008, 24 f***, 1 m*, MT, SW, YPT, H, J, P, Va, NMPC; Sedloňov - Polom (104), 10.viii.2005, 1 f*, MT, H, NMPC; Selské vrchy hills - Mlýnský potok brook (105), 19.ix.2001, 1 f*, MT, Ve, NMPC; Trčkov NNR (116), 29.vi.18.vii. and 18.vii.-5.viii.1994, 12.x.1999, 28.vii.2003, $11 \mathrm{f}^{*} *$, MT, MB, YPT, H, J, Va, NMPC; Velká louka meadow NM (123), 14.vii.1995, 24.vii.2008, $2 \mathrm{f}^{*} \mathrm{f}^{*}$, MT, SW, H, Mo, NMPC, MVCH; Zelenka (131), 11. and 14.viii., 3.ix.2009, $5 \mathrm{f}^{*} \mathrm{f}^{*}$, MT, H, NMPC; Zvonkové údolí valley (135), 21.vii.2003, $4 \mathrm{f}^{*} \mathrm{f}^{*}, 3 \mathrm{~m} \mathrm{~m}^{*}$, MT, H, NMPC.

Immature stages. Anenský vrch Mt. (3), 3 m*m* ex larvae collected 5.v.1999, H, J; eclosion v.1999, exuviae of larvae and pupae in the eth./coll. NMPC n. 176, 193, 199. Same (3), $3 \mathrm{f}^{*} \mathrm{f}^{*}$, ex larvae collected 5.v.1999, H, J; eclosion v.1999, exuviae of larvae and pupae in the eth./coll. NMPC n. 198, 200, 212 - one exuvia of pupa pinned. Pod Sfingou NM (90), $1 \mathrm{~m} *$ ex larvae collected 5.v.1999, H, J; eclosion v.1999, exuvia of larva and pupa in the eth./coll. NMPC n. 194. Same (90), $1 \mathrm{f*}$ ex larva collected 5.v.1999, H, J; eclosion v.1999, exuvia of larva and pupa in the eth./coll. NMPC n. 26. Rašeliniště Kačerov NR peatbog (98), $2 \mathrm{f}^{*} \mathrm{f}^{*}$ ex larvae collected 5.v.1999, H, J; eclosion v.1999, exuviae of larvae and pupae in the eth./coll. NMPC n. 196-197. Same (98), 3 $\mathrm{m} * \mathrm{~m} *$ ex larvae collected 5.v.1999, H, J; eclosion v.1999, exuviae of larvae and pupae in the eth./coll. NMPC $\mathrm{n}$. 174, 178, 195. Trčkov NNR (116), 2 m*m* ex larva collected 19.-22.iv.1999, H, J; eclosion v.1999, exuviae of larvae and pupae in the eth./coll. NMPC n. 23, 36. Same (116), 8 m*m* ex larvae collected 3.v.1999, H, J; eclosion v.1999, exuviae of larvae and pupae in the eth./coll. NMPC n. 42-43, 52-53, 164-165, 175, 205. Same (116), $5 \mathrm{f}^{*} \mathrm{f}^{*}$ ex larvae collected 19.-22.iv.1999, H, J; eclosion v.1999, exuviae of larvae and pupae in the eth./ 
coll. NMPC n. 15, 18-20, 28. Same (116), 6 f*f* ex larvae collected 3.-4.v.1999, H, J; eclosion v.1999, exuviae of larvae and pupae in the eth./coll. NMPC n. 153, 156, 177, 185, 206-207. Velká louka meadow NM (123), 12 m*m*, ex larvae collected 6.v.1999, H, J; eclosion v.1999, exuviae of larvae and pupae in the eth./coll. NMPC n. 155, 162, 167, 169, 173, 179, 180, 184, 187-190. Same (123), 9 f*f* ex larva collected 6.v.1999, H, J; eclosion v.1999, exuviae of larvae and pupae in the eth./coll. NMPC n. 170-172, 182-183, 201-204.

Comments. A European species discontinuously distributed from Portugal, Central Europe as far as the Caspian Sea. Larvae inhabit the littoral of small forest water reservoirs and meander flows in higher altitudes, and swamps with tufts of sedges and rushes (Carex, Juncus and Scirpus spp.).

\section{Haematopota subcylindrica Pandellé, 1883}

Published records. Moucha \& Chvála 1967: Česká Skalice, Karlova Studánka; Ježková 1974: Police nad Metují; Formánek 1982: Bohdaneč.

Comments. Known from Belgium, the Netherlands, Denmark and Sweden, Central and East Europe as far as West Siberia, Transcaucasia, Kazakhstan, Turkey and Iran. Larvae inhabit the littoral of small forest lakes and ponds, swamps and wet meadows.

\section{Heptatoma pellucens (Fabricius, 1776)}

Published records. Vimmer 1913, Moucha \& Chvála 1956a, b: Hradec Králové; Moucha \& Chvála 1961: Nové Město nad Metují; Ježková 1974: Karlov, Nový Bydžov; Formánek 1982: Bohdaneč.

Material examined. Adamovo jezero lake (1), 6.vii.2011, 7.vii.2012, $9 \mathrm{f}^{*} \mathrm{f}^{*}$, SW, J, NMPC; Bartošovice v Orlických horách (5), 3 f***, 20.-29.vi.1994, YPT, H, P, Va, NMPC; Dolní Morava (36), 29.v.2003, 1 f*, SW, J, NMPC; Dolní Radechová (37), 5.vi.1971, 1 f*, SW, Ms, MVCH; Hradec Králové - Nový Hradec Králové (49), 10.viii.1956 and 30.v.1958, 2 f*f*, SW, Z, MVCH; Lázně Bohdaneč - ponds (70), 16.vii.2003, 23.vi. and 7.vii.2004, 3 f***, MT, SW, C, J, M, NMPC; Na Plachtě NM (75), 3.vii.2000, 1 f*, SW, Mo, MVCH; Prameny near Žárová (92), 26.vii.1995, 1 f*, SW, J, NMPC; Skuhrov nad Bělou (108), 6.viii.1995, 1 f*, SW, J, NMPC; Studnice (110), 19.viii.2002, 1 f*, SW, J, NMPC; Trčkov NNR (116), 7.vi.2011, 2 f*f*, SW, H, J, S, NMPC.

Comments. A European-West-Siberian species, distributed up to the boreal forest zone near the Arctic Circle in Russia. In Europe ranging from France to coastal countries near the North Sea and Scandinavia; the southern limit of its distribution runs across Switzerland, Austria, Slovenia, Croatia, Hungary, Romania, Bulgaria and Ukraine. Chvála (1988) fully recognized Heptatoma pellucens orientalis Olsufjev, 1962 restricted only to Altai in his Palaearctic Catalogue. Larvae of the nominate form develop in the littoral zone of forest pools and water reservoirs of lowland parks (Chvála \& Ježek 1997).

\section{Summary of results and discussion}

This study summarizes both historical and recent faunistic data on horse flies obtained from the NE Hercynicum of CZ. The research was performed mainly in the period 1964 2012 (some specimens were colelcted between 1952 - 1963, moreover, a very small amount of material was added during the preparation of this paper) and 136 mostly new localities are listed. The diversity of the horse fly fauna of this area is relatively rich ( $36 \mathrm{spp}$. from 8 genera, including one ssp. and one recognized form): this is $65.5 \%$ of the horse flies species recorded from the Czech Republic. From a zoogeographical point of view, the horse fly fauna of the NE parts of the Hercynian mountains and adjacent localities is made up of species of Eurosiberian (15 spp., $41.66 \%$ ), European (9 spp., $25.0 \%$ ), Palaearctic (8 spp., $22.22 \%$ ), Holarctic (2 spp., $5.56 \%$ ), Subboreal (1 ssp., $2.78 \%$ ) and Submediterranean (1 sp., $2.78 \%$ ) distribution (see Table 1). The most interesting findings during our faunistic survey in the Hercynian localities are the records of nationally scarce Silvius alpinus, Hybomitra arpadi, $H$. kaurii and $H$. nitidifrons confiformis. Our field research did not confirm the continued occurence of the very rare species as Chrysops rufipes, Glaucops hirsutus and the nationally 
scarce Hybomitra lurida, known only from historical records. Atylotus plebejus and Chrysops rufipes are classified as endangered species in the Czech Republic, Glaucops hirsutus as vulnerable. The occurence periods of three species were extended in comparison with data of Chvála (1980): Chrysops viduatus - ix, Hybomitra bimaculata - viii and Haematopota scutellata - x. The highest number of horse flies was recorded in Lázně Bohdaneč - ponds (2634 specimens, 13 species) followed by Mělčany - Zlatý potok brook (464 specimens, 10 spp.) and Zelenka (349 specimens, 7 spp.). A third of all the studied sites (45 localities) yielded only a single Tabanid specimen. Haematopota pluvialis was the most frequently collected species in the study area (85 localities). On the other hand, Hybomitra ciureai was collected at only a single locality. Traps at five sites yielded a single horse fly species. Atylotus rusticus, Tabanus bovinus, T. quatuornotatus, T. spodopterus and Haematopota subcylindrica have become vanishing species due to the increasing negative impact of human activities. The species richness of this family depends on a future reasonable way of the stockfarming (populations of horses and cattle) and forestry management (populations of cervids), as well as on the maintenance of greater numbers of wetland biotopes in human-affected landscapes.

Acknowledgements: We thank to the staff of the Management of the Orlické hory PLA (Rychnov nad Kněžnou), Jeseníky PLA (Jeseník - Bukovice), Broumovsko PLA (Police nad Metují) and Králický Sněžník NNR - the Agency of Nature and Landscape Protection (Pardubice) for their support of our research. We are obliged to B. Mocek (Museum of Eastern Bohemia, Hradec Králové) for the loan of horse flies collected at more than 30 quite different localities. It is our pleasant duty to express thanks to R. Rozkošný (Faculty of Science of Masaryk University, Brno) and J. Zuska (Praha) for providing specimens from elsewhere. We are obliged to P. Chvojka, J. Macek, M. Mašínová, H. Studničková and O. Žd’árková (all National Museum, Praha) for their help in the field and the preparation of insects in the laboratory. This study was supported partially by the Ministry of Culture of the Czech Republic (DKRVO 2017/13, National Museum, Prague, 0002327201). Thanks are due to M. Kopeček (Brno), J. Mocek (Turnov), M. Tkoč (Praha) and V. Ježková (Praha) for providing photographs. We would like to thank Maxwell V. L. Barclay (London) for corrections and constructive comments on our English account.

\section{References}

Andreeva R.V. (1990): Opredelitel lichinok slepnei (Evropeiskaya chast SSSR, Kavkaz i Srednaya Azia). Key to larvae of horse flies (European part of USSR, Caucasus and Central Asia). Naukova Dumka, Kiev, 172 pp. (in Russian).

Chvála M. (1980): Tabanidae, pp. 282-390. In: Chvála M., Hůrka K., Chalupský J., Knoz J., Minář J. \& Országh I.: Krevsající mouchy a střečci - Diptera. Fauna ČSSR. [Blood-sucking flies and botflies - Diptera. Fauna of Czechoslovakia]. Vol. 22. Praha, 538 pp. (in Czech, English summary).

- (1988): Family Tabanidae, pp. 97-171. In: Soós A. (ed.): Catalogue of Palaearctic Diptera, Vol. 5 Athericidae - Asilidae. Akadémiai Kiadó, Budapest, 446 pp.

- (2007): Tabanidae. In: Pape T. (ed.): Fauna Europea: Diptera Brachycera. Version 1.3. Available online at http://www.faunaeur.org (last update on 19.iv.2007).

- (2009): Tabanidae Latreille, 1802. In: Jedlička L., Stloukalová V. \& Kúdela M. (eds): Checklist of Diptera of the Czech Republic and Slovakia. Electronic version 2. Comenius University, Bratislava. http://zoology.fns.uniba.sk/diptera + CD-ROM (ISBN 80-969629-0-6).

Chvála M. \& Ježek J. (1969): Immature stages of five European Hybomitra species of the bimaculata- and montana-groups (Diptera, Tabanidae). - Folia Parasitol. 16: 329-347.

- (1997): Diptera Tabanidae, Horse Flies, pp. 295-309. In: Nilsson A. (ed.): The aquatic Insects of North Europe. Vol. 2. Apollo Books, Stenstrup, 440 pp.

Chvála M., Lyneborg L. \& Moucha J. (1972): The horse flies of Europe (Diptera, Tabanidae). Publisher: Entomological Society of Copenhagen, $499 \mathrm{pp}$.

Czižek K. (1907): Neue Beiträge zur Dipterenfauna Mährens. - Z. Mähr. Landesmus., Brünn, 7: 157-177.

- (1908): II. Nachtrag zu den "Beiträgen zu einer Dipterenfauna Mährens”. - Z. Mähr. Landesmus., Brünn, 8: 126.

Dvořák L. (2011a): Some data to horsefly fauna (Diptera: Tabanidae) in south-eastern part of Bohemian Forest, Czech Republic, with notes to Hybomitra arpadi (Szilády, 1923). - Silva Gabreta, Vimperk, 17(2-3): 73-81. 
- (2011b): Ovádi (Diptera: Tabanidae) v okolí Kladské (CHKO Slavkovský les). The horse flies (Diptera: Tabanidae) in a vicinity of Kladská (Slavkovský les PLA). - Západočes. ent. listy 2: 44-50 (in Czech, Engl. abstract).

Ehrendorfer F. \& Hamann U. (1965): Vorschläge zu einer floristischen Kartierung von Mitteleuropa. - Ber. Deutsch. Bot. Gessel. 78: 35-50.

Faltysová H. et al. (2002): Královéhradecko. In: Mackovčin P. \& Sedláček M. (eds): Chráněná území ČR, svazek V. Agentura ochrany př́rody a krajiny ČR a Ekocentrum Brno, Praha, 410 pp.

- (2004): Pardubicko. In: Mackovčin P. \& Sedláček M. (eds): Chráněná území ČR, svazek IV. Agentura ochrany př́rody a krajiny ČR a Ekocentrum Brno, Praha, 316 pp.

Folco G.B. (1934): Osservazioni sullo sviluppo di Chrysozona (Haematopota) italica Meigen. - Mem. Soc. Toscana Sci. Nat. 44: 1-11.

Formánek L. (1982): Příspěvek k poznání čeledi ovádovitých (Diptera, Tabanidae) ve státní př́rodní rezervaci Bohdanečský rybník a rybník Matka. - Práce a studie - Př́ŕr., Pardubice 13-14: 125-131.

Ježek J. (1971): Larven und Puppen der Art Heptatoma pellucens (Fabr.) und vier europäischen Arten der Gattung Haematopota Meigen (Diptera, Tabanidae). - Acta Ent. Bohemoslov. 68: 341-351.

- (1977a): Larvae and pupae of three European Hybomitra species (Diptera, Tabanidae). - Acta Ent. Mus. Nat. Pragae 39: 191-207.

- (1977b): Keys to the last instar larvae and pupae of some European Tabanidae (Diptera). - Acta Ent. Bohemoslov. 74: 339-344.

- (1980): Ovádovití - Tabanidae, pp. 415-422. In: Rozkošný R. (ed.): Klíč vodních larev hmyzu. Identification key to aquatic larvae of insects. Academia, Praha, 521 pp. (in Czech).

- (1995): Revision of collections of horse flies (Diptera, Tabanidae) - faunistics, additions, grid-mapping, new records (part II). - Čas. Nár. Muz., Ř. Př́r. 164: 124-126.

- (1999): Tabanidae, pp.131-138. In: Rozkošný R. \& Vaňhara J. (eds): Diptera of the Pálava Biosphere Reserve of UNESCO, I. - Folia Fac. Sci. Nat. Univ. Masaryk. Brun., Biol. 99(1998): 1-219.

Ježek J. \& Barták M. (2000): Tabanidae, pp.133-137. In: Barták M. \& Vaňhara J. (eds): Diptera in an industrially affected region (north-western Bohemia, Bílina and Duchcov environs). I. - Folia Fac. Sci. Nat. Univ. Masaryk. Brun., Biol. 104: 1-240.

- (2005): Čeled’: Tabanidae (ovádovití), pp. 276-277. In: Farkač J., Král D. \& Škorpík M. (eds): Červený seznam ohrožených druhů České republiky. Bezobratlí. Red list of threatened species in the Czech Republic. Invertebrates. Agentura ochrany př́rody a krajiny ČR, Praha, 760 pp. (in Czech and English).

Ježek J., Barták M., Gregor T. \& Kubík Š . (2005): Tabanidae, pp.122-127. In: Barták M. \& Kubík Šs. (eds): Diptera of Podyjí National Park and its environs. Česká zemědělská univerzita v Praze, Fakulta agrobiologie, potravinových a prírodních zdrojů, Praha, $432 \mathrm{pp}$.

Ježek J., Barták M., Vaněk J. \& Kubík Š. (2012): Ovádovití (Diptera, Tabanidae) české části Krkonoš. Tabanidae (Diptera) in the Czech part of the Krkonoše Mts. - Opera Corcon. 49: 173-180.

Ježek J. \& Heřman P. (2014): Ovádovití (Diptera: Tabanidae) Českého krasu. Horse flies (Diptera: Tabanidae) of the Český kras/ Bohemian Karst (Czech Republic). - Bohemia Centr., Praha 32: 345-355.

Ježek J. \& Ježková V. (1978): Some results of grid-mapping of horse flies (Diptera, Tabanidae) in Czechoslovakia, pp.119-142. In: Országh I. (ed.): Dipt. Bohemoslov. 1. Veda, Bratislava, 357 pp.

Ježek J., Krupauerová A., Barták M. \& Kubík Š. (2012): Tabanidae (Diptera) of Vráž env. Písek (southern Bohemia, Czech Republic), pp. 74-80. In: Kubík Š. \& Barták M. (eds): Proceedings of the „Workshop on biodiversity“, Jevany, 3.-4.th July, 2012. Česká Zemědělská Univerzita v Praze, Fakulta Agrobiologie, Potravinových a př́rodních zdrojů, 203 pp.

Ježek J. \& Omelková M. (2012): Horse flies (Diptera: Tabanidae) of the Bílé Karpaty Protected Landscape Area and Biosphere Reserve (Czech Republic). - Acta Mus. Morav., Sci. biol., Brno 96(2): 803-817.

Ježek J., Vonička P. \& Preisler J. (2008): Ovádovití (Diptera: Tabanidae) Jizerských hor a Frýdlantska. (Tabanidae (Diptera) of the Jizerské hory Mts and Frýdlant region (northern Bohemia, Czech Republic). - Sb. Severočes. Muz., Př́r.V. 26: 187-200.

Ježková V. (1974): Současný stav faunistického výzkumu čeledi ovádovitých (Insecta, Diptera, Tabanidae) na území ČSSR. Present state of faunistic research of horse flies (Insecta, Diptera, Tabanidae) on the territory of Czechoslovakia. Dissertation Thesis, Pedagogical Faculty, Charles University, Praha, 99 pp. (In Czech, unpubl. manuscript).

Landrock K. (1907): Mährische Zweiflügler. - Acht. Ber. Lehr. Nat. 1906/1907: 50-71.

- (1932): Die Bremsen (Tabanidae) Mährens. - Verhandl. nat. Ver. Brünn 63(1931): 133-151.

Leclercq M. (1960): Révision systématique et biogéographique des Tabanidae (Diptera) paléarctiques. Vol. 1: Pangoniinae et Chrysopsinae. - Mém. Inst. R. Sci. Nat. Belg. 63: 1-77.

- (1967): Révision systématique et biogéographique des Tabanidae (Diptera) paléarctiques. Vol. 2: Tabaninae. Mém. Inst. R. Sci. Nat. Belg. 80(1966): 1-237.

Moucha J. (1976): Horse-flies (Diptera: Tabanidae) of the World. Synoptic Catalogue. - Acta Ent. Mus. Nat. 
Pragae, Suppl. 7: 1-319.

Moucha J. \& Chvála M. (1955): Revise ovádovitých (Dipt., Tabanidae) Československa (I. část: Chrysopinae). Revision der Tabaniden (Diptera) der Tschechoslowakei (I. Teil: Chrysopinae). - Zool. ent. Listy 4(3): 227-238.

- (1956a): Revise ovádovitých (Dipt., Tabanidae) sbírky Vimmerovy. Revision der Tabaniden (Diptera) aus Ant. Vimmer's Sammlung. - Př́r. Sb. Ostrav. Kr. 17: 147-151 (in Czech, German summary).

- (1956b): Revise ovádovitých (Dipt., Tabanidae) Československa (II. část: Haematopotinae). Revision der Tabaniden (Diptera) der Tschechoslowakei (II. Teil: Haematopotinae). - Zool. Listy, Brno 5: $259-270$ (in Czech, German summary).

- (1956c): Revise ovádovitých (Dipt., Tabanidae) sbírky Moravského musea. Revision der Bremsen (Dipt., Tabanidae) aus der Sammlung des Mährischen Museums. - Čas. Morav. Mus. 41: 87-92.

- (1958): Revise ovádovitých (Dipt., Tabanidae) Československa (III. část: Tabaninae: Tabanus s. str.). Revision der Tabaniden (Diptera) der Tschechoslowakei (III. Teil: Tabaninae: Tabanus s. str.). - Zool. Listy, Brno 7: 182-197 (in Czech, German summary).

- (1959a): K poznání ovádovitých (Diptera, Tabanidae) v Rychlebských horách. Zur Erkenntnis der Bremsen (Dipt. Tabanidae) des Reichensteiner Gebirges. In: Rychlebské hory. - Sb. prac. přír. poměr., Ostrava, pp. 301-305 (in Czech, German summ.).

- (1959b): Revise ovádovitých (Dipt., Tabanidae) Československa (IV. část: Tabaninae 2). Revision der Tabaniden (Diptera) der Tschechoslowakei (IV. Teil: Tabaninae 2). - Zool. Listy, Brno 8: 161-174 (in Czech, German summary).

- (1959c): K poznání ovádovitých Moravy a Slovenska. Zur Kenntnis der Tabaniden-Fauna Mährens und der Slowakei. - Čas. Slez. Muz. Opava (A) 8: 119-126 (in Czech, German summ.).

- (1961): K poznání ovádovitých Československa. Zur Kenntnis der Tabaniden-Fauna der Tschechoslowakei. Acta Mus. Silesiae, Ser. A., Opava 10: 57-61.

- (1967): Beschreibung des Männchens von Haematopota scutellata nebst Bemerkungen über die Gattung Haematopota Meig. in der Tschechoslowakei (Diptera, Tabanidae). - Acta Ent. Bohemoslov. 64: $224-231$.

- (1968): Die Gattung Hybomitra Enderlein, 1922 in der Tschechoslowakei (Diptera, Tabanidae). - Acta Faun. Ent. Mus. Nat. Pragae 12: 263-294.

- (1969): Zur Kenntnis der Bremsengattung Atylotus Osten-Sacken in der Tschechoslowakei (Diptera, Tabanidae). - Acta Ent. Bohemoslov. 66: 321-329.

Olsufjev N.G. (1977): Tabanidae. Fauna USSR. No. 7(2). Leningrad, 434 pp. (in Russian).

Omelková M., Ježek J., Starý J., Roháček J. \& Holinka J. (2008): Dvoukř́́dlí (Diptera). True flies (Diptera), pp. 294-298, 304-305. In: Jongepierová I. (ed.): Louky Bílých Karpat. Grasslands of the White Carpathian Mountains. ZOČSOP Bílé Karpaty, Veselí nad Moravou, 461 pp. (in Czech and English).

Pape T., Blagoderov V. \& Mostovski M.B. (2011): Order Diptera Linnaeus, 1758. In: Zhang Z.-Q. (ed.) Animal biodiversity: An outline of higher-level classification and survey of taxonomic richness. - Zootaxa 3148: 222-229.

Pruner L. \& Míka P. (1996): Seznam obcí a jejich částí v České republice s čísly mapových polí pro sít’ové mapování fauny. List of settlements in the Czech Republic with associated map field codes for faunistic grid mapping system. - Klapalekiana 32 (Suppl.): 1-115 (in Czech, English summary).

Šafář J. et al. (2003): Olomoucko. In: Mackovčin P. \& Sedláček M. (eds): Chráněná území ČR, svazek VI. Agentura ochrany př́rody a krajiny ČR a Ekocentrum Brno, Praha, 456 pp.

Teskey H.J. (1990): The Horse Flies and Deer Flies of Canada and Alaska. Diptera: Tabanidae. - Ins. Arach. Canada 16: 1-381.

Vimmer A. 1913: Seznam českého hmyzu dvoukřídlého. Catalogus dipterorum. - Ent. přír. 8: 1-99 (in Czech).

Zelený J. (1972): Návrh členění Československa pro faunistický výzkum. Entwurf einer Gliederung der Tschechoslowakei für Zwecke der faunistischen Forschung. - Zpr. Českoslov. Spol. Ent. ČSAV 8: 3-16 (in Czech, German summary).

Authors' addresses: Jan Ježek, Department of Entomology, National Museum, Cirkusová 1740, CZ-193 00 Praha 9 - Horní Počernice, Czech Republic

E-mail: jan.jezek@o2active.cz

Markéta Omelková*, Department of Botany and Zoology, Faculty of Science, Masaryk

University, Brno, Kotlářská 2, CZ-611 37, Czech Republic

*corresponding author, E-mail: marketa.omelkova@seznam.cz;

Josef Hájek, Sopotnice 41, CZ-561 15, Czech Republic

E-mail: josehajek@gmail.cz 


\section{Appendix:}

Tab 1: Systematic list of 36 species (incl. one ssp.) of horse flies (Diptera: Tabanidae) known from the NE parts of the Hercynian mountains and its environs; a recognized form of bimaculata is added. Abbreviations: EUR European, EUS - Eurosiberian, HOL - Holarctic, PAL - Palaearctic, SBB - Subboreal, SBM Submediterranean; EN - endangered, VU - vulnerable, NS - nationally scarce.

\begin{tabular}{|c|c|c|c|c|}
\hline List of taxa & distribution & $\begin{array}{c}\text { conservation } \\
\text { status }\end{array}$ & $\begin{array}{c}\text { recent occurrence } \\
\text { of adults in the } \\
\text { studied area }\end{array}$ & $\begin{array}{c}\text { Chvála (1980): } \\
\text { occurrence } \\
\text { in CZ and SK }\end{array}$ \\
\hline Chrysops caecutiens (Linnaeus, 1758) & EUS & & v-viii & v-ix \\
\hline Chrysops relictus Meigen, 1820 & EUS & & vi-viii & vi-ix \\
\hline Chrysops rufipes Meigen, 1820 & EUS & EN & - & vi-viii \\
\hline Chrysops viduatus (Fabricius, 1794) & EUS & & vi-ix & vi-viii \\
\hline Silvius alpinus (Scopoli, 1763) & EUR & NS & vii & v-viii \\
\hline Atylotus plebejus (Fallén, 1817) & PAL & EN & vii & vii-viii \\
\hline Atylotus rusticus (Linnaeus, 1767) & EUS & & viii & vi-ix \\
\hline Glaucops hirsutus (Villers, 1789) & EUR & $\mathrm{VU}$ & - & vii-viii \\
\hline Hybomitra arpadi (Szilády, 1923) & $\mathrm{HOL}$ & NS & $\mathrm{vi}$ & vi-vii \\
\hline Hybomitra auripila (Meigen, 1820) & EUR & & v-vii & v-viii \\
\hline Hybomitra bimaculata (Macquart, 1826) & PAL & & v-viii & v-vii \\
\hline Hybomitra bimaculata f. bisignata (Jaennicke, 1866) & PAL & & vi & - \\
\hline Hybomitra ciureai (Ségui, 1937) & EUS & & vi-viii & $\mathrm{v}$-ix \\
\hline Hybomitra distinguenda (Verrall, 1909) & PAL & & vi-viii & v-viii \\
\hline Hybomitra kaurii Chvála \& Lyneborg, 1970 & PAL & NS & vi & v-vii \\
\hline Hybomitra lundbecki Lyneborg, 1959 & PAL & & v-vii & iv-vii \\
\hline Hybomitra lurida (Fallén, 1817) & $\mathrm{HOL}$ & NS & - & iv-vi \\
\hline Hybomitra micans (Meigen, 1804) & EUR & & v-viii & v-viii \\
\hline Hybomitra montana Meigen, 1820 & PAL & & v-vii & v-viii \\
\hline Hybomitra muehlfeldi (Brauer, 1880) & PAL & & v-viii & v-viii \\
\hline Hybomitra nitidifrons confiformis Chvála \& Moucha, 1971 & SBB & NS & $\mathrm{v}$-vi & v-vii \\
\hline Hybomitra tropica (Linnaeus, 1758) & EUR & & $\mathrm{v}$-vi & $\mathrm{v}$-vi \\
\hline Tabanus autumnalis Linnaeus, 1761 & PAL & & v-ix & $\mathrm{v}-\mathrm{x}$ \\
\hline Tabanus bovinus Linnaeus, 1758 & EUS & & vi-vii & v-ix \\
\hline Tabanus bromius Linnaeus, 1758 & EUS & & vi-ix & $\mathrm{v}$-ix \\
\hline Tabanus cordiger Meigen, 1820 & EUR & & vi-vii & $\mathrm{v}$-ix \\
\hline Tabanus glaucopis Meigen, 1820 & EUS & & vii-viii & vi-ix \\
\hline Tabanus maculicornis Zetterstedt, 1842 & EUS & & v-viii & v-viii \\
\hline Tabanus quatuornotatus Meigen, 1820 & SBM & & - & iv-vii \\
\hline Tabanus spodopterus Meigen, 1820 & EUR & & - & v-viii \\
\hline Tabanus sudeticus Zeller, 1842 & EUS & & vii-viii & vi-viii \\
\hline Haematopota crassicornis Wahlberg, 1848 & EUS & & v-viii & $\mathrm{v}$-ix \\
\hline Haematopota italica Meigen, 1804 & EUR & & vii-viii & v-ix \\
\hline Haematopota pluvialis (Linnaeus, 1758) & EUS & & vi-ix & vi-x \\
\hline Haematopota scutellata (Olsufjev, Moucha \& Chvála, 1964) & EUR & & vi- $\mathrm{x}$ & vi-ix \\
\hline Haematopota subcylindrica Pandellé, 1883 & EUS & & - & v-ix \\
\hline Heptatoma pellucens (Fabricius, 1776) & EUS & & v-viii & $\mathrm{v}$-ix \\
\hline
\end{tabular}

